\title{
The Pepper Calmodulin Gene CaCaM1 Is Involved in Reactive Oxygen Species and Nitric Oxide Generation Required for Cell Death and the Defense Response
}

\author{
Hyong Woo Choi, Dong Hyuk Lee, and Byung Kook Hwang \\ Laboratory of Molecular Plant Pathology, School of Life Sciences and Biotechnology, Korea University, Anam-dong, \\ Sungbuk-ku, Seoul 136-713, Republic of Korea
}

Submitted 2 March 2009. Accepted 24 June 2009.

Calcium signaling has emerged as an important signal transduction pathway of higher plants in response to biotic and abiotic stresses. $\mathrm{Ca}^{2+}$-bound calmodulin (CaM) plays a critical role in decoding and transducing stress signals by activating specific targets. Here, we isolated and functionally characterized the pathogen-responsive $\mathrm{CaM}$ gene, Capsicum annuum calmodulin 1 (CaCaM1), from pepper (C. annuum) plants. The cellular function of $\mathrm{CaCaM1}$ was verified by Agrobacterium spp.-mediated transient expression in pepper and transgenic overexpression in Arabidopsis thaliana. Agrobacterium spp.-mediated transient expression of $\mathrm{CaCaM1}$ activated reactive oxygen species (ROS), nitric oxide (NO) generation, and hypersensitive response (HR)-like cell death in pepper leaves, ultimately leading to local acquired resistance to Xanthomonas campestris pv. vesicatoria. CaCaM1overexpression (OX) Arabidopsis exhibited enhanced resistance to Pseudomonas syringae and Hyaloperonospora parasitica, which was accompanied by enhanced ROS and NO generation and HR-like cell death. Treatment with the calcium-channel blocker suppressed the oxidative and NO bursts and HR-like cell death that were triggered by CaCaM1 expression in pepper and Arabidopsis, suggesting that calcium influx is required for the activation of $\mathrm{CaCaM1}$ mediated defense responses in plants. Upon treatment with the CaM antagonist, virulent $P$. syringae pv. tomato-induced NO generation was also compromised in CaCaM1-OX leaves. Together, these results suggest that the $\mathrm{CaCaM1}$ gene functions in ROS and NO generation are essential for cell death and defense responses in plants.

Plants initiate fine-tuned downstream signal transduction cascades in response to attempted invasion by pathogens (Fujita et al. 2006; Jones and Dangl 2006). Many cellular compounds, such as $\mathrm{Ca}^{2+}$, lipids, $\mathrm{H}^{+}$, cyclic nucleotides, and inositolphosphates, are suggested to be second messengers used by plants during the signal transduction cascade (Durner et al. 1998; Sanders et al. 1999). Among them, $\mathrm{Ca}^{2+}$ can be stored in apoplasts or special organelles such as the vacuole and endo-

Corresponding author: Byung Kook Hwang; Telephone: +82-32903061; Fax: +82-9211715; E-mail: bkhwang@korea.ac.kr

Nucleotide sequence data of $\mathrm{CaCaM1}$ from this article can be found in the GenBank data libraries under accession number EU935058.

* The $e$-Xtra logo stands for "electronic extra" and indicates that three supplemental figures are published online and that Figures 6 and 8 appear in color online. plasmic reticulum and can be rapidly released into cytoplasm when it is needed (Sanders et al. 1999, 2002; Gao et al. 2004). It is known that an increase in cytosolic free calcium $\left(\left[\mathrm{Ca}^{2+}\right]_{\text {cyt }}\right)$ is one of the earliest responses to biotic and abiotic stresses in plant cells (Knight and Knight 2001; White and Broadley 2003; Lecourieux et al. 2006; Ma and Berkowitz 2007).

In many plant-pathogen interactions, a $\mathrm{Ca}^{2+}$ influx has been demonstrated to be essential for the activation of plant defense responses, including the oxidative burst and hypersensitive cell death (Price et al. 1994; Harding et al. 1997; Xu and Heath 1998; Blume et al. 2000; Grant et al. 2000). Infection of resistant but not susceptible cowpea (Vigna unguiculata) with a rust fungus (Uromyces vignae) results in prolonged elevation of $\left[\mathrm{Ca}^{2+}\right]_{\text {cyt }}$ levels at the site of infection (Xu and Heath 1998). In addition, treatment of plant cells with $\mathrm{Ca}^{2+}$ chelators, $\mathrm{Ca}^{2+}$ channel blockers, or $\mathrm{Ca}^{2+}$-bound calmodulin $(\mathrm{CaM})$ antagonists compromises the oxidative burst and hypersensitive cell death (Blume et al. 2000; Grant et al. 2000; Ma et al. 2008). AvrRpt2-induced membrane depolarization, electrolyte leakage, and the hypersensitive response (HR) are compromised in Arabidopsis leaves treated with the $\mathrm{Ca}^{2+}$ channel blocker lanthanum chloride $\left(\mathrm{LaCl}_{3}\right)$ (Pike et al. 2005). Application of $\mathrm{CaM}$ antagonist $\mathrm{N}$-(6-aminohexyl)-5-chloro-1-naphthalenesulfonamide (W7) blocked pathogen-induced nitric oxide (NO) generation and the HR in Arabidopsis plants (Ma et al. 2008).

The calcium ion $\left(\mathrm{Ca}^{2+}\right)$ plays pivotal roles in plant defense responses, either by directly activating a group of enzymes called calcium-dependent protein kinases (CDPK) (Roberts 1993; Romeis et al. 2001; Ludwig et al. 2004) or by indirectly activating target proteins through $\mathrm{Ca}^{2+}$-binding proteins, such as CaM (Kim et al. 2002; Bouché et al. 2005; Popescu et al. 2007; Rainaldi et al. 2007). CaM, a ubiquitous $\mathrm{Ca}^{2+}$-binding protein in eukaryotes, transduces $\mathrm{Ca}^{2+}$ signals by modulating the activity of diverse CaM-binding proteins. Recently, a large number of target proteins bound to $\mathrm{CaM}$ proteins were screened using a high-density Arabidopsis protein microarray (Popescu et al. 2007). The CaM-targeted proteins included transcription factors, receptor and intracellular protein kinases, F-box proteins, RNA-binding proteins, and proteins of unknown function, which suggests possible roles for CaM proteins in diverse signal transduction pathways. However, the majority of targets were specific to one or a few CaM proteins, indicating that different $\mathrm{CaM}$ family members function through different targets.

Multiple $C a M$ genes have been shown to encode numerous $\mathrm{CaM}$ isoforms in potato, tomato, tobacco, Arabidopsis, rice, and soybean (Lee et al. 1995; Takezawa et al. 1995; Bergey and Ryan 1999; Yamakawa et al. 2001; Day et al. 2002; Reddy 
et al. 2002; Boonburapong and Buaboocha 2007). CaM isoforms from diverse plant species exhibit differential expression patterns in response to biotic and abiotic stimuli. In tobacco plants containing the $N$ resistance gene (Nicotiana tabacum L., cv. Samsun NN), 13 CaM genes (NtCaMl to -13) are regulated transcriptionally and post-transcriptionally in response to wounding and Tobacco mosaic virus infection (Yamakawa et al. 2001). The soybean CaM genes SCaM4 and SCaM5 are differentially induced by fungal elicitors or pathogens; however, other highly conserved CaM genes are not induced by pathogens. Constitutive expression of SCaM4 and SCaM5 in transgenic tobacco produces spontaneous leaf lesions reminiscent of hypersensitive cell death and induces the expression of several defense-related genes (Heo et al. 1999). Recently, $\left[\mathrm{Ca}^{2+}\right]_{\mathrm{cyt}}$ elevation has been suggested to be linked to downstream NO generation through the action of $\mathrm{CaM}$ or calmodulin-like proteins (Ma et al. 2008). Although such accumulating evidence indicates pivotal roles for the CaM genes in diverse biotic and abiotic stresses, the in vivo biological roles of multiple $\mathrm{CaM}$ isoforms are largely unknown.

In this study, we have isolated and functionally characterized a novel pepper CaM gene, Capsicum annuum calmodulin 1 $(\mathrm{CaCaM1})$, induced in pepper plants $(C$. annuum L.) that were infected by an avirulent strain of Xanthomonas campestris pv. vesicatoria. RNA gel blot analyses revealed distinct expression profiles of $\mathrm{CaCaMI}$ under biotic and abiotic stress conditions.

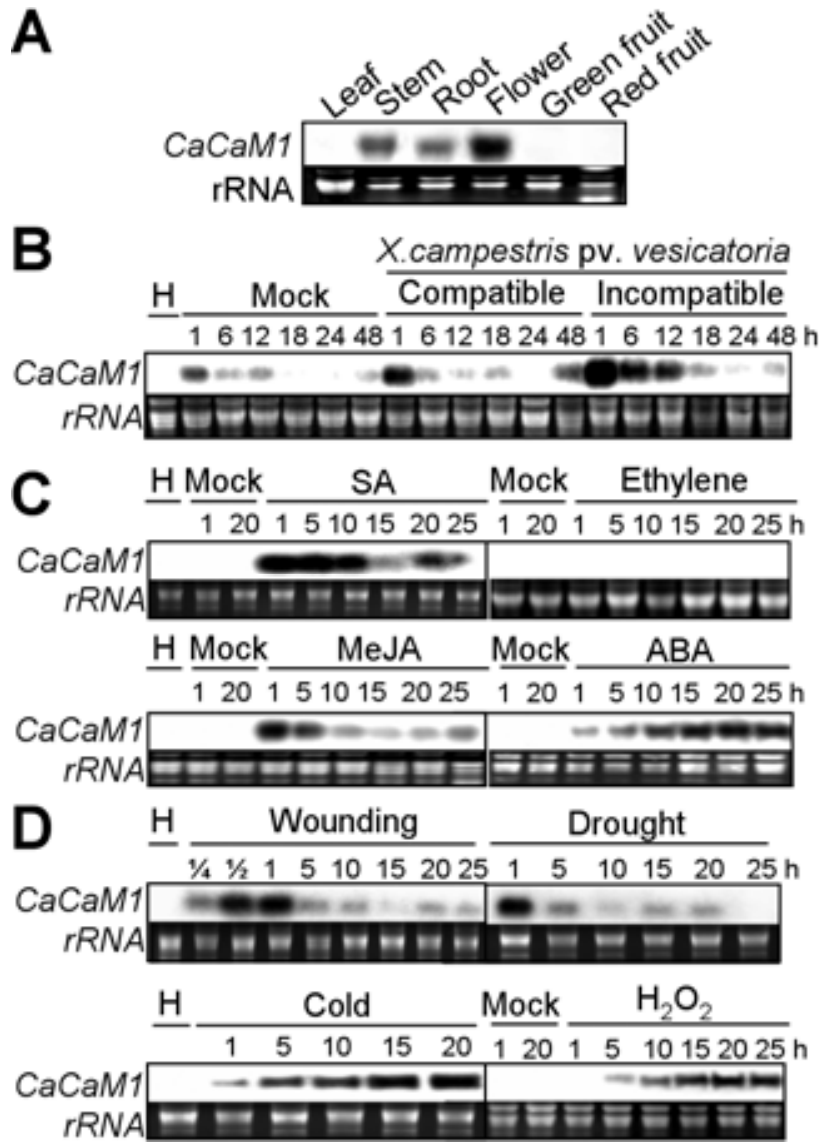

Fig. 1. RNA gel blot analyses of Capsicum annuum calmodulin 1 (CaCaM1) in pepper plants. A, Expression levels of $\mathrm{CaCaM1}$ in various organs. $\mathbf{B}$, Temporal expression patterns of $\mathrm{CaCaM1}$ in leaves inoculated with the virulent (compatible) Ds1 and avirulent (incompatible) Bv5-4a strains of Xanthomonas campestris pv. vesicatoria. $\mathrm{H}$ : uninoculated healthy leaves; Mock: $10 \mathrm{mM} \mathrm{MgCl}_{2}$-inoculated. $\mathbf{C}$, Temporal expression patterns of CaCaM1 in leaves treated with abiotic elicitors. SA: salicylic acid, MeJA: methyl jasmonate, ABA: abscisic acid. D, Temporal expression patterns of CaCaM1 in leaves subjected to environmental stresses.
Agrobacterium spp.-mediated transient expression analyses also revealed a role for $C a C a M 1$ in the defense responses of pepper plants, such as the generation of reactive oxygen species (ROS) and NO, pathogenesis-related $(P R)$ gene induction, and hypersensitive cell death, which occur during pathogen recognition in plants. Furthermore, transgenic expression of CaCaMl in Arabidopsis conferred an altered resistance to biotrophic, hemibiotrophic, and necrotrophic pathogens.

\section{RESULTS}

\section{Isolation and sequence analysis} of the pepper $\mathrm{CaCaM1}$ gene.

To isolate pepper genes induced during the HR, we performed macro cDNA array analysis using a cDNA library made from pepper leaves infected with the avirulent strain Bv5-4a of $X$. campestris pv. vesicatoria (Jung and Hwang 2000). One of the genes upregulated during the HR, designated $C a C a M 1$, showed high sequence identity to plant $C a M$ genes (Supplementary Fig. 1). Sequence analysis of CaCaMI revealed that $\mathrm{CaCaM1}$ contains an open reading frame (ORF) encoding a putative 149 -amino-acid protein, with a calculated molecular mass of $16.8 \mathrm{kDa}$. BLAST analysis indicated that the deduced amino acid sequence of $C a C a M 1$ contains four conserved elongation factor (EF)-hand motifs that bind to four $\mathrm{Ca}^{2+}$ molecules. In plants, all known $\mathrm{CaM}$ genes possess $\mathrm{EF}$ hands, unique $\mathrm{Ca}^{2+}$ binding sites composed of a characteristic helix-loop-helix motif (Day et al. 2002; Boonburapong and Buaboocha 2007).

The $\mathrm{Ca}^{2+}$-binding site in the EF hands of CaCaM1 was compared with the consensus sequences of typical plant CaMs. $\mathrm{Ca}^{2+}$-coordinating residues in $\mathrm{CaCaM} 1$, indicated by asterisks, are invariably identical to those of the plant $\mathrm{CaM}$ consensus sequences. Other residues in the $\mathrm{Ca}^{2+}$-binding loop were also conserved in $\mathrm{CaCaM} 1$, except for phenylalanine $(\mathrm{F})$ at residue 2 of the fourth EF hand (no. 4).

\section{Expression of $\mathrm{CaCaM1}$ in pepper plants.}

To examine the steady-state expression level of CaCaM1 in various organs of pepper plants, total RNAs were extracted from leaves, stems, roots, flowers, and green and red fruit. CaCaM1 transcripts were most abundant in flower tissues, whereas lower levels were observed in stem and root tissues (Fig. 1A). CaCaMl transcripts were not detected in leaf and green and red fruit tissues. We next examined the temporal expression patterns of $C a C a M 1$ in pepper leaves during the $X$. campestris pv. vesicatoria infection (Fig. 1B). CaCaM1 transcripts were not detected in healthy leaves. However, $\mathrm{CaCaMI}$ was apparently induced $1 \mathrm{~h}$ after mock inoculation or inoculation with the virulent strain Ds1 (compatible) and avirulent strain Bv5-4a (incompatible) of $X$. campestris pv. vesicatoria. In particular, the expression of $\mathrm{CaCaMl}$ was rapid and prolonged in avirulent $X$. campestris pv. vesicatoria-inoculated pepper leaves compared with mock- or virulent $X$. campestris pv. vesicatoria-inoculated leaves. The $\mathrm{CaCaMI}$ transcript levels drastically decreased 6 to $12 \mathrm{~h}$ after $X$. campestris pv. vesicatoria inoculation.

We further examined the expression patterns of $\mathrm{CaCaM1}$ in response to abiotic elicitors (Fig. 1C) or environmental stresses (Fig. 1D). Salicylic acid (SA), ethylene, jasmonic acid (MeJA), and abscisic acid (ABA) act as important signaling molecules in plants, and exogenous application of these chemicals activates complex defense signaling pathways (Zeevaart and Creelman 1998; Glazebrook 2001). CaCaMI transcripts were strongly induced within $1 \mathrm{~h}$ and maintained up to $10 \mathrm{~h}$ after treatment with $5 \mathrm{mM} \mathrm{SA}$. Although the experiments were performed three times, we could not detect 
$\mathrm{CaCaM1}$ transcripts in ethylene-treated pepper leaves. Treatment with MeJA induced CaCaM1 expression within $1 \mathrm{~h}$, but the induction decreased remarkably $10 \mathrm{~h}$ after treatment. Following $100 \mu \mathrm{M}$ ABA treatment, $\mathrm{CaCaMl}$ transcripts began to accumulate within $1 \mathrm{~h}$ and gradually increased up to $25 \mathrm{~h}$.

We next analyzed time-course expression patterns of CaCaMl under various environmental stress conditions (Fig. 1D). The CaCaM1 gene was strongly induced within $1 \mathrm{~h}$ after drought and wounding stresses but induction decreased remarkably after $5 \mathrm{~h}$. Cold and oxidative stress (hydrogen peroxide $\left.\left[\mathrm{H}_{2} \mathrm{O}_{2}\right]\right)$ treatment gradually elevated $\mathrm{CaCaMl}$ transcript levels. The expression patterns induced by cold and $\mathrm{H}_{2} \mathrm{O}_{2}$ treatment were similar to those induced by ABA treatment. Together, the RNA gel blot analyses revealed that $\mathrm{CaCaM1}$ was differentially induced by various biotic and abiotic stresses, except for ethylene exposure.

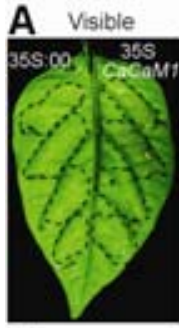

B
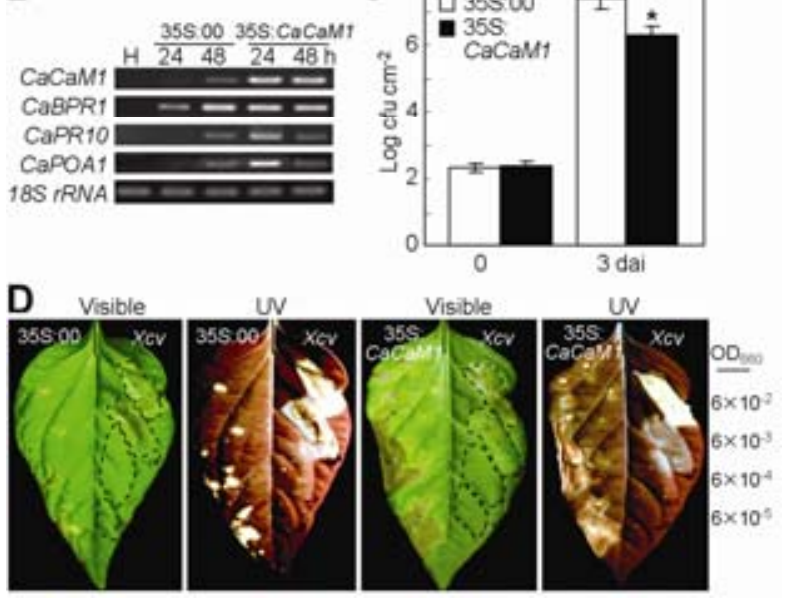

Fig. 2. Activation of cell death and defense responses in pepper leaves by Agrobacterium spp.-mediated transient expression of Capsicum annuum calmodulin 1 ( $C a C a M 1)$. A, Induction of cell death and reactive oxygen species in pepper leaves infiltrated with Agrobacterium tumefaciens strains carrying the empty vector pBIN35S (35S:00) or the pBIN35S:CaCaM1 construct (35S:CaCaM1) within the regions indicated by the dashed lines. Visible: Visible symptoms on pepper leaves 4 days after agroinfiltration. UV: UV-exposure of pepper leaves to visualize the deposition of fluorescent pigments and chlorosis. Cleared: Decolorization of pepper leaves in ethanol to clearly visualize the necrotic lesions. DAB: 3,3'-diaminobenzidine staining $24 \mathrm{~h}$ after agroinfiltration. B, Reverse-transcription polymerase chain reaction analyses of expression of the CaCaM1 gene and defense-related genes in pepper leaves 24 and $48 \mathrm{~h}$ after agroinfiltration. C, Bacterial growth in right halves of pepper leaves challenge-inoculated with the virulent Xanthomonas campestris pv. vesicatoria strain Ds $1\left(5 \times 10^{4}\right) 2$ days after prior agroinfiltration into the left half areas of leaves; dai: days after inoculation. Data are the means \pm standard deviations from three independent experiments. Asterisks indicate significant differences as determined by Student's $t$ test $(P<0.05)$. D, Disease symptoms developed in pepper leaves 4 days after challenge inoculation with virulent $X$. campestris pv. vesicatoria. Right halves of pepper leaves were challenge inoculated with virulent $X$. campestris pv. vesicatoria 2 days after infiltration with A. tumefaciens strains carrying empty vector $(35 \mathrm{~S}: 00)$ or the 35S:CaCaM1 construct into left halves of pepper leaves. Similar results were obtained from the three independent experiments.
Activation of cell death and defense response

in pepper by transient expression of $\mathrm{CaCaM1}$.

To examine the in vivo function of $\mathrm{CaCaMl}$ in defense responses, we used the virus-induced gene silencing (VIGS) technique in pepper plants, as previously described (Choi et al. 2007, 2008). However, we could not establish CaCaM1silenced pepper plants due to lethality. Pepper seedlings infiltrated with Agrobacterium spp. carrying a CaCaMl silencing construct failed to develop mature leaves (data not shown). Thus, we used an Agrobacterium spp.-mediated transient expression system to analyze the in vivo function of $\mathrm{CaCaMI}$ in pepper plants. Necrotic lesions developed around sites infiltrated with Agrobacterium spp. carrying the 35S:CaCaM1 construct but not the empty vector control (35S:00) (Fig. 2A). To visualize cell death or chlorotic symptoms, we observed pepper leaves under UV light 4 days after agroinfiltration. Interestingly, fluorescent pigments were strongly induced in and around $\mathrm{CaCaMl}$-expressing regions (Fig. $2 \mathrm{~A}$, UV). Furthermore, necrotic cell death and strong $\mathrm{H}_{2} \mathrm{O}_{2}$ accumulation was observed in $\mathrm{CaCaMl-expressing} \mathrm{regions} \mathrm{when} \mathrm{leaves}$ were cleared by ethanol and stained with 3,3'-diaminobenzidine (DAB), respectively. However, cell death and $\mathrm{H}_{2} \mathrm{O}_{2}$ induction were not seen in pepper leaves infiltrated with Agrobacterium spp. carrying the empty vector (35S:00). In these leaves, mild chlorosis was detected in pepper leaves, as observed under UV light (optical density at $600 \mathrm{~nm}\left[\mathrm{OD}_{600}\right]$ of 0.5 and 0.2 ). We further used CaM antagonist $\mathrm{W} 7$ to examine in vivo function of $\mathrm{CaCaM} 1$ for the $\mathrm{NO}$ generation and cell death regulation. However, the exogenous application of W7 did not alter $\mathrm{CaCaM1-induced} \mathrm{hypersensitive} \mathrm{cell} \mathrm{death} \mathrm{in}$ pepper leaves (Supplementary Fig. 2). We also were not able to detect significant difference in NO generation of pepper leaves infiltrated with Agrobacterium spp. carrying 35S:CaCaM1 in the presence or absence of W7 (data not shown).

The transcript levels of $\mathrm{CaCaM1}$ and several defense-related genes were investigated by reverse-transcription polymerase chain reaction (RT-PCR) (Fig. 2B). These levels strongly increased in pepper leaves 24 and $48 \mathrm{~h}$ after infiltration with Agrobacterium spp. carrying 35S:CaCaM1. However, low levels of $C a C a M 1$ transcripts were detected in empty vector con-

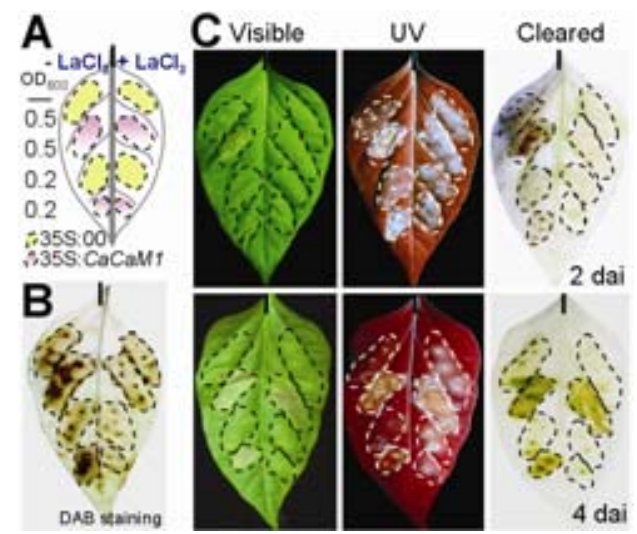

Fig. 3. Reduction of Capsicum annuum calmodulin 1 (CaCaM1)-induced cell death and reactive oxygen species (ROS) in pepper leaves by co-infiltration with the calcium-channel blocker lanthanum chloride $\left(\mathrm{LaCl}_{3}\right)$. A, Schematic diagram of Agrobacterium spp.-mediated transient expression of $\mathrm{CaCaM1}$ in pepper leaves in the presence or absence of $\mathrm{LaCl}_{3}$. B, Detection of ROS in pepper leaves by staining with $3,3^{\prime}$ diaminobenzidine $24 \mathrm{~h}$ after agroinfiltration. C, Cell death and defense responses of pepper leaves. Visual: Visual symptoms on pepper leaves 2 and 4 days after agroinfiltration (dai). UV: UV exposure of pepper leaves to visualize the deposition of fluorescent pigments and chlorosis. Cleared: Decolorization of pepper leaves in ethanol to clearly visualize the necrotic lesions. 
trol (35S:00) leaves $48 \mathrm{~h}$ after agroinfiltration. The expression of basic pathogenesis-related protein 1 (CaBPR1), pathogenesis-related protein 10 (CaPR10), and ascorbate peroxidase 1 ( $\mathrm{CaPOAl}$ ) was more rapid and strong in $\mathrm{CaCaMl-expressing}$ pepper leaves than in empty vector-infiltrated leaves.

To examine the function of $C a C a M 1$ in the defense response of pepper plants to $X$. campestris pv. vesicatoria infection, the left halves of leaves were infiltrated with Agrobacterium spp. carrying the 35S:00 or 35S:CaCaM1 constructs. Two days after agroinfiltration, the right halves of the leaves were challenge inoculated with the virulent $X$. campestris pv. vesicatoria Ds1.X. campestris pv. vesicatoria growth was significantly reduced in $\mathrm{CaCaM1-expressing} \mathrm{pepper} \mathrm{leaves.} \mathrm{Approximately}$ 10-fold lower bacterial growth was observed in $\mathrm{CaCaM1-}$ expressing pepper leaves compared with empty vector control leaves (35S:00) (Fig. 2C). Furthermore, disease symptoms were reduced in the $\mathrm{CaCaM1}$-expressing pepper leaves compared with empty vector control leaves (Fig. 2D). Empty vector control leaves but not of $\mathrm{CaCaM1}$-expressing leaves became severely waterlogged and developed necrotic lesions 4 days after inoculation with $X$. campestris pv. vesicatoria Ds1 at $10^{6} \mathrm{CFU} \mathrm{ml^{-1 }}$.

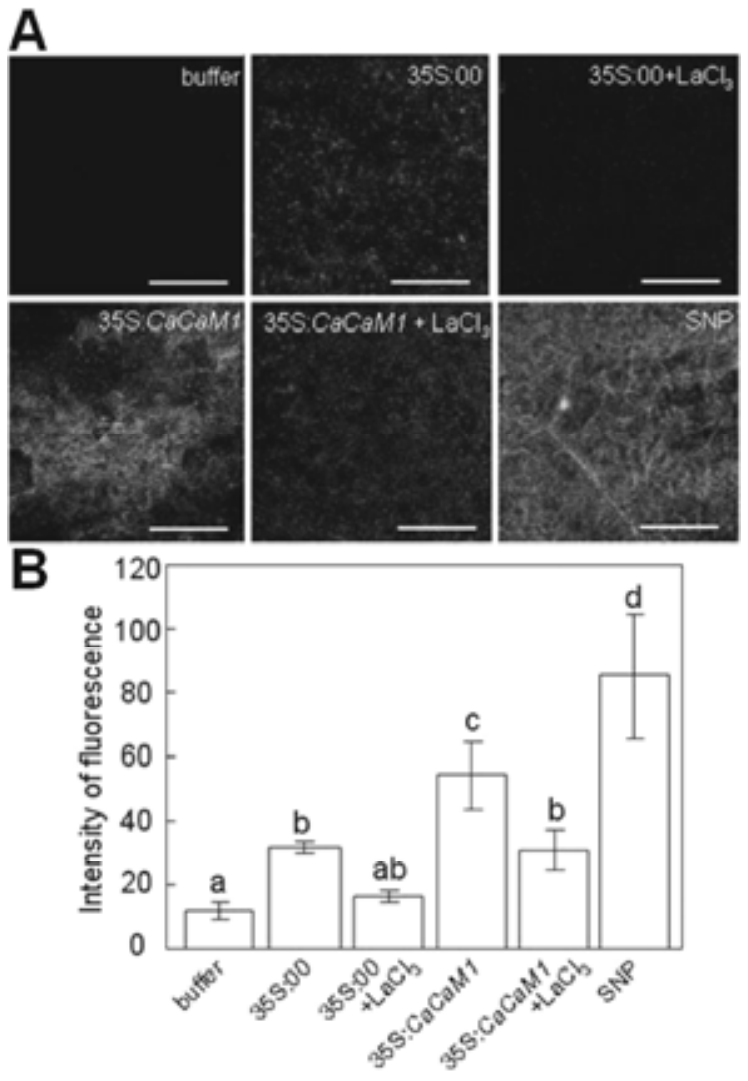

Fig. 4. Induction of the nitric oxide (NO) burst by Agrobacterium spp.-mediated transient expression of Capsicum annuиm calmodulin 1 ( $\mathrm{CaCaMI})$ in pepper leaves. A, Effect of the transient expression of $\mathrm{CaCaM1}$ on the NO burst in the presence or absence of the calcium-channel blocker lanthanum chloride $\left(\mathrm{LaCl}_{3}\right)$. Pepper leaves were infiltrated with Agrobacterium tumefaciens carrying the indicated constructs with or without $\mathrm{LaCl}_{3}$. Pepper leaves were infiltrated with $12.5 \mu \mathrm{M}$ 4,5-diaminofluorescein diacetate (DAF-2 DA) solution to detect NO $24 \mathrm{~h}$ after agroexpression. Sodium nitroprusside (SNP; $500 \mu \mathrm{M})$ was co-infiltrated into leaves with DAF-2 DA as a positive control. The infiltrated leaf areas were monitored $1 \mathrm{~h}$ after DAF-2 DA infiltration under the confocal scanning laser microscope. Bars $=100 \mu \mathrm{m}$. B, Quantification of signal intensities by color histogram analysis. Data are the means \pm standard deviations from three independent experiments. Statistically significant difference between means were determined by employing the least significant difference test $(P=0.05)$.

\section{Requirement for calcium channel activation in $\mathrm{CaCaM1-induced} \mathrm{cell} \mathrm{death.}$}

An increase in $\left[\mathrm{Ca}^{2+}\right]_{\text {cyt }}$ is required for the activation of various plant $\mathrm{Ca}^{2+}$-binding sensor proteins, such as CDPK, CaM, and NADPH oxidase (Day et al. 2002). To address the relationship between $\left[\mathrm{Ca}^{2+}\right]_{\text {cyt }}$ increase and $\mathrm{CaCaM1}$-induced defense responses, we used a calcium channel blocker, $\mathrm{LaCl}_{3}$, which is known to effectively inhibit the $\left[\mathrm{Ca}^{2+}\right]_{\text {cyt }}$ increase in plants (Grant et al. 2000). Predictably, co-infiltration of Agrobacterium spp. carrying the 35S:CaCaM1 construct with $\mathrm{LaCl}_{3}$ solution greatly inhibited $\mathrm{CaCaMI}$-induced $\mathrm{H}_{2} \mathrm{O}_{2}$ accumulation (Fig. 3A and B). Furthermore, $\mathrm{CaCaMl-induced} \mathrm{HR-like}$ cell death also was delayed or compromised in the presence of $\mathrm{LaCl}_{3}$ (Fig. 3A and C).

Recently, CaM or the CaM-like protein was proposed to intermediate innate immune signaling between a $\left[\mathrm{Ca}^{2+}\right]_{c y t}$ increase and the downstream NO burst that is necessary for the development of the HR (Ali et al. 2007; Ma et al. 2008). To investigate whether the $\mathrm{CaCaMl}$-induced defense response also involves NO generation, CaCaMl was transiently expressed in pepper leaves using agroexpression to detect the NO burst by 4,5-diaminofluorescein diacetate (DAF-2DA)-mediated fluorescence (Fig. 4). Sodium nitroprusside (SNP), a NO generator, was used as a positive control for DAF-2DA-mediated fluorescence. Pepper leaves treated with SNP exhibited a significantly high level of DAF-2DA-mediated fluorescence

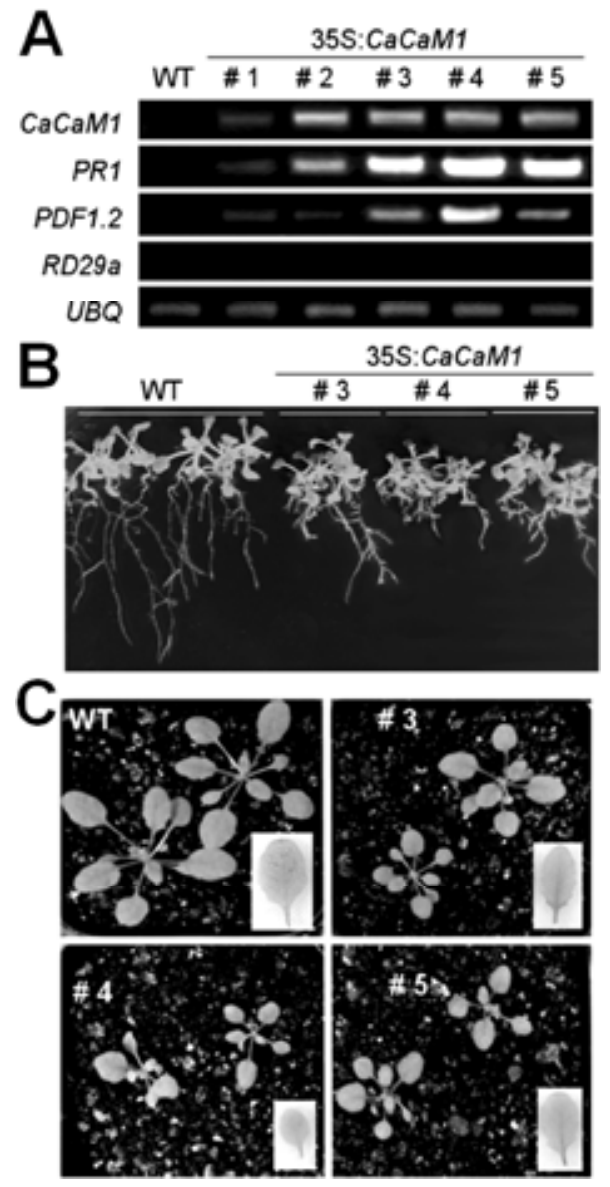

Fig. 5. Generation of Capsicum annuum calmodulin 1 overexpression (CaCaM1-OX) transgenic Arabidopsis plants. A, Reverse-transcription polymerase chain reaction analyses of expression of the CaCaM1, PRI, $P D F 1.2$, and RD29A genes in 4-week-old wild-type and transgenic plants. B, Comparison of growth of wild-type and transgenic plants grown on MS plates for 15 days. C, Comparison of growth of wild-type and transgenic plants grown on soil for 4 weeks. 
(Fig. 4A). Agroexpression of CaCaM1 (35S:CaCaM1) also strongly induced fluorescence signals in pepper leaves compared with plants infiltrated with the empty vector control (35S:00); however, co-infiltration of $\mathrm{LaCl}_{3}$ significantly compromised NO generation in $\mathrm{CaCaMl}$-expressing regions (Fig. 4A and B). Infiltration with Agrobacterium spp. carrying the empty vector (35S:00) also increased DAF-2DA-mediated fluorescence in pepper leaves compared with mock-inoculated leaves (buffer). This could be due to endogenous expression of $\mathrm{CaCaM1}$ in pepper leaves infiltrated with Agrobacterium spp. carrying the empty vector (35S:00) (Fig. 2B). These data indicate that the $\left[\mathrm{Ca}^{2+}\right]_{\text {cyt }}$ rise is required for the activation of CaCaMl-mediated ROS and NO generation during HR-like cell death.

\section{$P R$ gene expression}

in $\mathrm{CaCaM1-overexpression} \mathrm{transgenic} \mathrm{Arabidopsis.}$

It is time-consuming and very difficult to generate transgenic pepper plants. Therefore, we overexpressed $\mathrm{CaCaM1}$ in Arabidopsis to determine its cellular functions in plants. To do this, the ORF region of the gene was integrated between the Cauliflower mosaic virus (CaMV)35S promoter and the nos terminator region in the binary vector pBIN35S. Arabidopsis thaliana ecotype Columbia (Col-0) plants were transformed by the floral dipping method (Clough and Bent 1998) using the Agrobacterium tumefaciens GV3101 carrying the pBIN35S:CaCaM1 construct. RT-PCR analysis was performed to determine expression levels of the transgene in transgenic Arabidopsis. The 35S:CaCaM1 transgenic lines selected by kanamycin resistance phenotype in Murashige-Skoog (MS) media expressed $\mathrm{CaCaMI}$ to various degrees (Fig. 5A).

We examined whether overexpression of $\mathrm{CaCaMI}$ triggers the expression of defense-related genes in transgenic Arabidopsis (Fig. 5A). CaCaM1-overexpression (CaCaM1-OX) transgenic plants showed significantly enhanced $P R I$ and PDF1.2 expression compared with wild-type plants. Further- more, a high overexpression of $\mathrm{CaCaM1}$ in transgenic line 4 induced higher levels of $P R I$ and $P D F 1.2$ gene expression than was seen in other transgenic lines. This finding suggests that the ectopic expression of $\mathrm{CaCaMl}$ in Arabidopsis triggers $P R$ gene expression. However, ABA-responsive RD29A transcripts (Knight and Knight 2001) were not detected in wildtype and CaCaM1-OX transgenic lines. We also observed growth retardation of CaCaMl-OX transgenic lines (Fig. 5B and $\mathrm{C}$ ). However, $\mathrm{H}_{2} \mathrm{O}_{2}$ accumulation and cell death were not detected in CaCaM1-OX transgenic leaves, as observed by $\mathrm{DAB}$ or trypan blue staining (data not shown).

\section{Distinct basal defense responses of $\mathrm{CaCaM1-OX}$} transgenic Arabidopsis to pathogen infection.

RT-PCR analyses revealed that the ectopic expression of CaCaMl triggers constitutive expression of PRI in Arabidopsis (Fig. 5A). To test whether the elevated expression levels of PRI correlated with disease resistance, we inoculated wildtype and CaCaM1-OX transgenic Arabidopsis with Pseudomonas syringae pv. tomato DC3000. Wild-type plants exhibited more severe chlorotic disease symptoms than transgenic plants did 7 days after spray inoculation with $P$. syringae pv. tomato DC3000 (10 $\left.\mathrm{CFU} \mathrm{ml}^{-1}\right)$ (Fig. 6A). Approximately 10fold lower bacterial growth was observed in CaCaMl-OX transgenic plants compared with wild-type plants (Fig. 6B). To analyze the induction of ROS and cell death in CaCaMl-OX transgenic plants, we used DAB (to detect $\mathrm{H}_{2} \mathrm{O}_{2}$ ) and trypan blue (to detect cell death) to stain leaves infected by $P$. syringae pv. tomato DC3000 (Fig. 6C). Strong and differential staining with DAB and trypan blue was observed in CaCaM1OX transgenic leaves 12 and $24 \mathrm{~h}$ after inoculation with $P$. syringae pv. tomato DC3000, respectively. We next examined PR1 expression levels in wild-type and CaCaM1-OX transgenic plants $24 \mathrm{~h}$ after mock and $P$. syringae pv. tomato DC3000 inoculation by RNA gel blot analysis (Fig. 6D). RNA gel blot analyses revealed that $\mathrm{CaCaM1-OX}$ transgenic plants
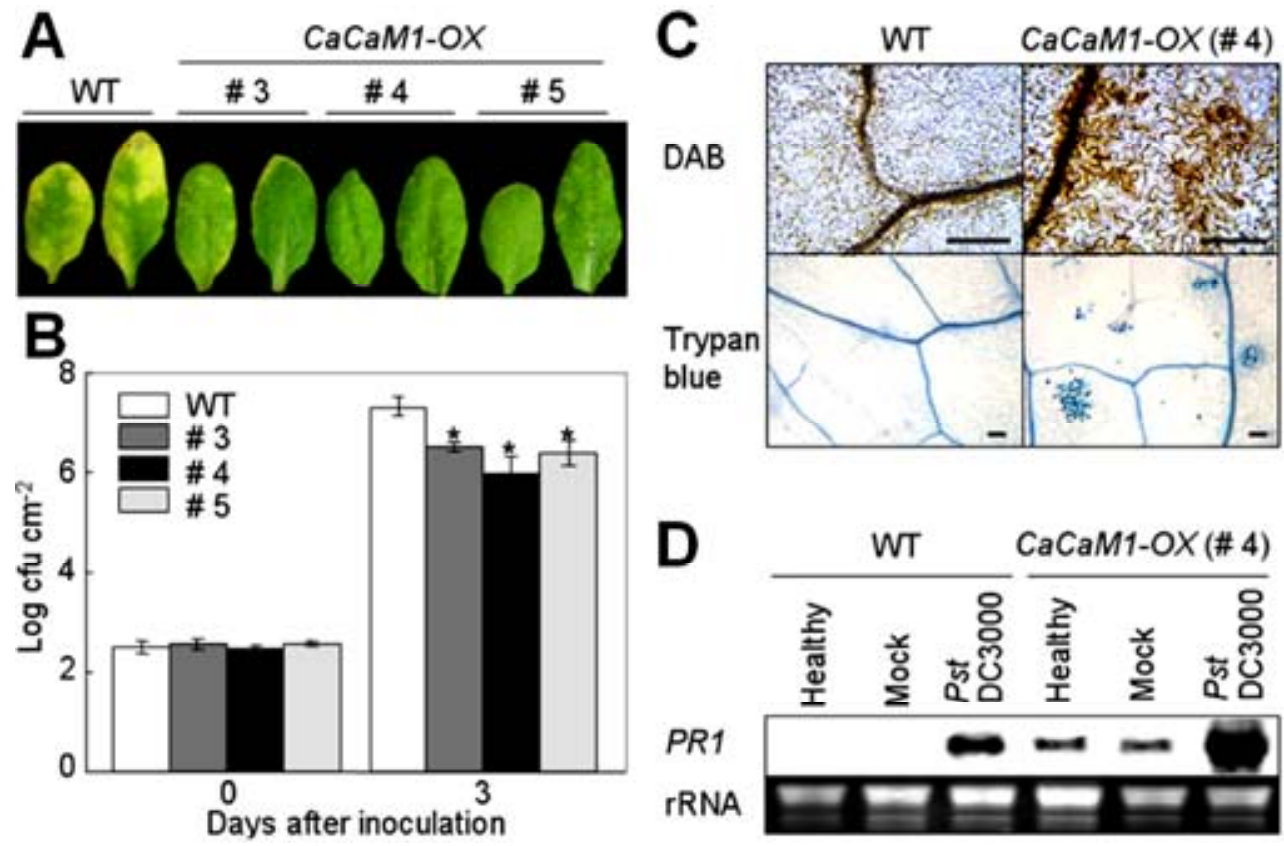

Fig. 6. Enhanced resistance of Capsicum annuum calmodulin 1 overexpression (CaCaM1-OX) transgenic Arabidopsis plants against Pseudomonas syringae pv. tomato DC3000. A, Disease symptoms on wild-type and transgenic plants 7 days after inoculation with $P$. syringae pv. tomato DC3000. B, Bacterial growth in leaves of wild-type and transgenic plants 0 and 3 days after spray inoculation $\left(10^{5} \mathrm{CFU} \mathrm{ml} \mathrm{m}^{-1}\right)$. Data are the means \pm standard deviations from three independent experiments. Asterisks indicate significant difference as determined by Student's $t$ test $(P<0.05)$. C, 3,3'-Diaminobenzidine (DAB) and trypan blue staining of $P$. syringae pv. tomato DC3000-infected leaves of wild-type and transgenic plants. DAB and trypan blue staining was performed 12 and $24 \mathrm{~h}$ after inoculation, respectively. Bars $=100 \mu \mathrm{m}$. D, RNA gel blot analysis of expression of the PR1 gene in wild-type and transgenic plants $24 \mathrm{~h}$ after mock $(10$ $\mathrm{mM} \mathrm{MgCl} 2)$ and $P$. syringae pv. tomato DC3000 $\left(10^{5} \mathrm{CFU} \mathrm{ml}^{-1}\right)$ inoculation by the foliar spray method. 
constitutively expressed $P R I$ in uninoculated healthy leaves. Interestingly, $\mathrm{CaCaM1-OX}$ transgenic plants exhibited a high level of PRI expression during P. syringae pv. tomato DC3000 infection compared with wild-type plants (Fig. 6D).

Next, we examined whether transgenic expression of CaCaM1 confers enhanced NO generation in Arabidopsis leaves during $P$. syringae pv. tomato DC3000 infection. The CaCaM1OX transgenic Arabidopsis but not wild-type plants distinctly produced DAF-2DA-mediated fluorescence $12 \mathrm{~h}$ after inoculation with $P$. syringae pv. tomato DC3000 compared with mockinoculated plants (Fig. 7). This indicates that the ectopic expression of $\mathrm{CaCaMl}$ in Arabidopsis enhanced NO generation during P. syringae pv. tomato DC3000 infection. Consistent with the results of the agroexpression experiments (Fig. 4), co-infiltration of $\mathrm{LaCl}_{3}$ with $P$. syringae pv. tomato significantly compromised the NO burst in CaCaMl-OX Arabidopsis plants, suggesting that $\mathrm{CaCaM1}$ functions in the increase in $\left[\mathrm{Ca}^{2+}\right]_{\text {cyt. }}$. Exogenous application of $\mathrm{CaM}$ antagonist $\mathrm{W} 7$ but not of its inactive structural analog $\mathrm{N}$-(6-aminohexyl)-1-naphthalenesulfonamide (W5) also compromised $P$. syringae pv. tomato DC3000-induced NO generation (Fig. 7) and symptom development in CaCaM1-OX Arabidopsis leaves (Supplementary Fig. 3). Infiltration of SNP, the NO generator, strongly produced DAF-2DAmediated fluorescence in both the wild type and $\mathrm{CaCaM1-OX}$ Arabidopsis. Taken together, these results indicate that ectopic expression of $\mathrm{CaCaMl}$ enhanced the basal defense of Arabidopsis to $P$. syringae pv. tomato DC3000 infection by increasing the generation of ROS and NO, which ultimately led to HR-like cell death and $P R$ gene expression.

We further evaluated whether overexpression of $\mathrm{CaCaMI}$ also enhances disease resistance to the biotrophic oomycete pathogen Hyaloperonospora parasitica $(\mathrm{Hp})$ infection. Seven days after inoculation, the cotyledons of wild-type plants produced significantly more sporangiophores than did those of transgenic plants (Fig. 8A and B). Approximately 50\% of the cotyledons of wild-type plants exhibited heavy sporulation (>20 sporangiophores/cotyledon) in contrast to only $20 \%$ of the cotyledons of transgenic plants (Fig. 8B). The average number of sporangiophores was significantly lowered in CaCaM1-OX transgenic lines (line 1: 18.3, line 2: 16.8, and line 3: 17.4) compared with wild-type plants (22.7). To analyze ROS accumulation and cell death in CaCaM1-OX transgenic plants, we stained leaves infected by $H$. parasitica isolate Noco2 with DAB and trypan blue (Fig. 8C and D, respectively). DAB distinctly stained cotyledons of CaCaMl-OX transgenic lines 1 and 3 days after inoculation with $H$. parasitica isolate Noco2 (Fig. 8C). Furthermore, cell death was observed around the infection sites of cotyledons of $\mathrm{CaCaM1-}$ OX transgenic lines 3 days after inoculation with $H$. parasitica isolate Noco2 (Fig. 8D). These results indicate that overexpression of $\mathrm{CaCaMl}$ confers enhanced basal resistance against the biotrophic oomycete pathogen $H$. parasitica, accompanied by the induction of ROS and cell death.

Ectopic expression of CaCaM1 in Arabidopsis triggered constitutive expression of PDF1.2 (Fig. 5A). Expression of PDF1.2 in Arabidopsis, dependent on an MeJA-dependent pathway, may be significant in triggering the resistance response to necrotrophic pathogens (Thomma et al. 1998). To determine whether the enhanced expression of PDF1.2 correlates with resistance response to necrotrophic fungal pathogens, we inoculated 4-week-old wild-type and $\mathrm{CaCaM1-OX}$ transgenic plants with the Alternaria brassicicola isolate KACC40036.
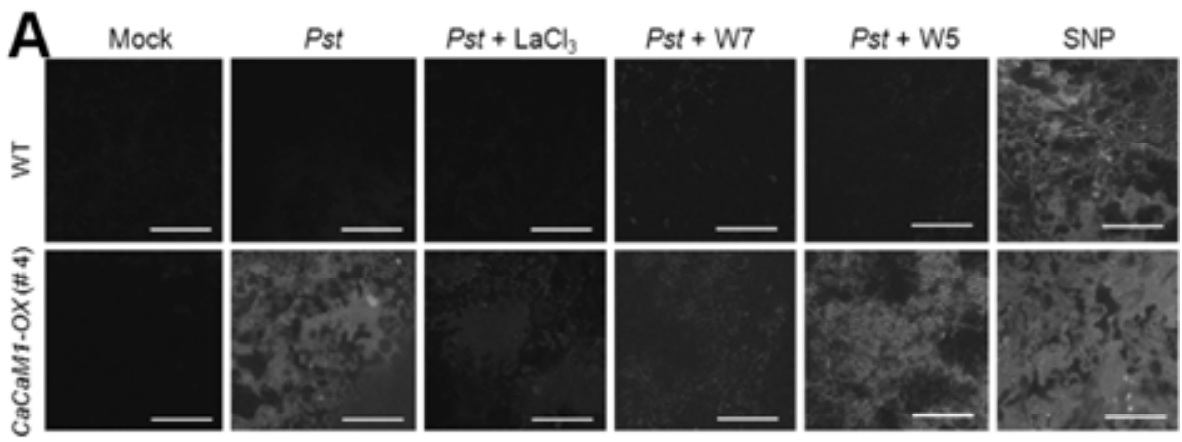

B

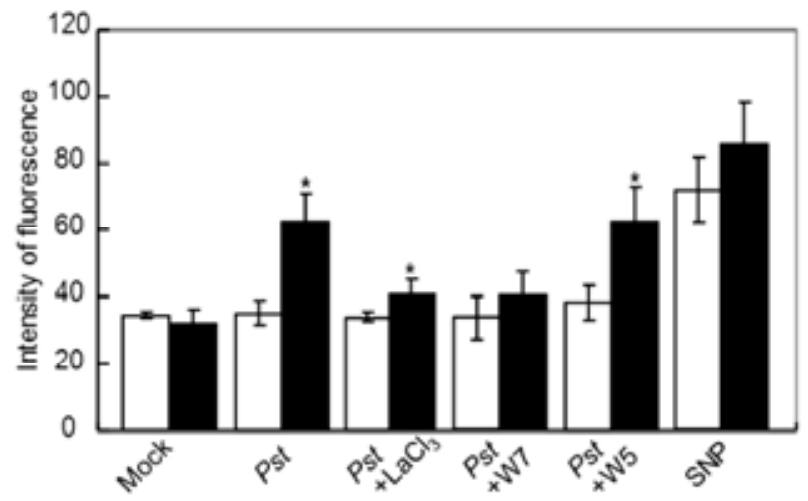

Fig. 7. Nitric oxide (NO) burst in leaves of wild-type (WT) and Capsicum annuum calmodulin 1 overexpression (CaCaM1-OX) transgenic Arabidopsis plants inoculated with virulent Pseudomonas syringae pv. tomato DC3000 in the presence or absence of the calcium channel blocker lanthanum chloride ( $\left.\mathrm{LaCl}_{3}\right), \mathrm{CaM}$ antagonist $N$-(6-aminohexyl)-5-chloro-1-naphthalenesulfonamide (W7), and inactive W7 structural analog $N$-(6-aminohexyl)-1-naphthalenesulfonamide (W5). A, Effect of transgenic expression of CaCaM1 on NO burst in leaves inoculated with P. syringae pv. tomato DC3000 supplemented with or without $\mathrm{LaCl}_{3}, \mathrm{~W} 7$, and W5. Arabidopsis leaves were infiltrated with $12.5 \mu \mathrm{M} 4,5$-diaminofluorescein diacetate (DAF-2 DA) solution 24 h after mock (10 $\left.\mathrm{mM} \mathrm{MgCl}{ }_{2}\right)$ and $P$. syringae pv. tomato DC3000 ( $\left.10^{7} \mathrm{CFU} \mathrm{ml}^{-1}\right)$ inoculation. Sodium nitroprusside (SNP; $\left.500 \mu \mathrm{M}\right)$ was co-infiltrated into leaves with DAF-2 DA as a positive control. The infiltrated leaf areas were monitored $1 \mathrm{~h}$ after DAF-2 DA infiltration by confocal scanning laser microscopy. Bars $=100 \mu \mathrm{m}$. B, Quantification of signal intensities by color histogram analysis. Data are the means \pm standard deviations from three independent experiments. Asterisks indicate significant differences as determined by Student's $t$ test $(P<0.05)$. 
Analysis of repetitive experiments revealed that distinctive disease symptoms did not develop in wild-type plants after infection with $A$. brassicicola isolate KACC40036. However, CaCaM1-OX transgenic plants showed chlorotic disease symptoms as well as enlarged necrotic lesions around the infection sites 7 days after inoculation (Fig. 9A and B). Lactophenol trypan blue staining was performed to visualize host cell death and fungal growth. Both wild-type and $\mathrm{CaCaM1-OX}$ transgenic plants exhibited host cell death response at the infection sites (Fig. 9C). However, prolific mycelial growth of $A$. brassicicola was observed only in transgenic plants but not in wild-type plants. These findings suggest that the ectopic expression of CaCaM1 enhanced the susceptibility of Arabidopsis plants to the necrotrophic fungal pathogen $A$. brassicicola.

\section{DISCUSSION}

Multigene families of CaM, a ubiquitous $\mathrm{Ca}^{2+}$-binding protein, are involved in various physiological processes in plants (Luan et al. 2002; Boonburapong and Buaboocha 2007). Calcium ion $\left(\mathrm{Ca}^{2+}\right)$ functions as a second messenger in plant defense signaling pathways by activating various $\mathrm{Ca}^{2+}$-binding proteins, including $\mathrm{CaM}, \mathrm{CDPK}$, calcineurin B-like proteins, and respiratory burst oxidase homologues (Cheng et al. 2002; Luan et al. 2002; Torres et al. 2005; Boonburapong and Buaboocha 2007). Some of these CaM families exhibit diverse expression patterns under stressful conditions, suggesting pivotal roles for $\mathrm{CaM}$ in defense responses in plants (Yamakawa et al. 2001; Takabatake et al. 2007). Despite considerable efforts in investigating $\mathrm{CaM}$ family proteins, their individual biological functions in disease resistance have not been identified. In the present study, we have isolated and functionally characterized a novel pathogen-induced pepper ( $C$. annuиm) $\mathrm{CaM}$ gene $(\mathrm{CaCaMI})$ in generating oxidative and $\mathrm{NO}$ bursts relevant to cell death and defense responses in pepper plants. Our RNA gel blot analyses revealed the rapid and prolonged expression of $\mathrm{CaCaM1}$ in pepper leaves inoculated with avirulent $X$. campestris pv. vesicatoria, which triggered early resistance responses, including the oxidative burst, the HR, and defense-marker gene induction, compared with virulent $X$. campestris pv. vesicatoria (Lee and Hwang 2005; Choi et al. 2007). The increased and prolonged expression of $\mathrm{CaCaMI}$ suggests that this gene may function in the resistance response of pepper plants against $X$. campestris pv. vesicatoria infection. In Arabidopsis, comparisons of global transcriptomes between plants exhibiting compatible and incompatible interactions with virulent and avirulent $P$. syringae pv. tomato strains revealed that differences in defense-related gene expression between susceptibility and resistance are quantitative and temporal rather than qualitative (Glazebrook 2001). Plant defense-related signaling hormones SA and MeJA are known to cross-talk to fine-tune defense responses to biotrophic and necrotrophic pathogen infection, respectively (Koornneef and Pieterse 2008). Treatment of pepper plants with SA induced stronger and more prolonged expression of CaCaMl compared with wounding and MeJA treatment. The expression
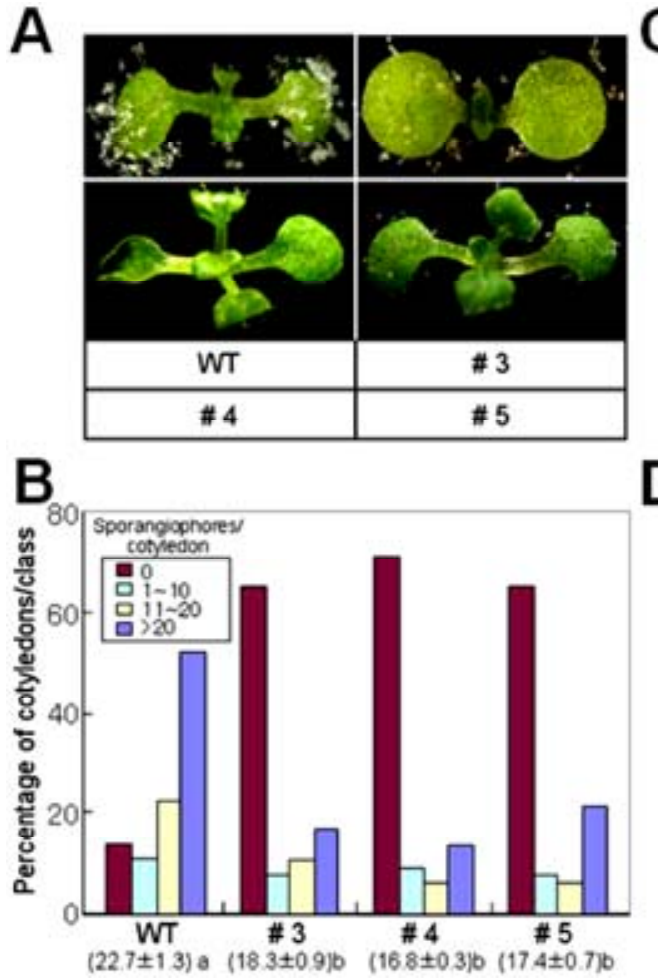
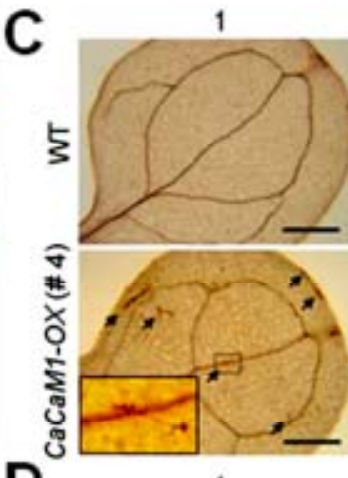

1

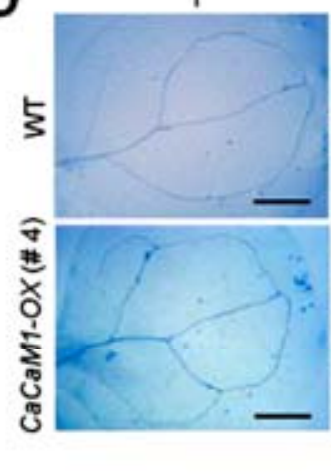

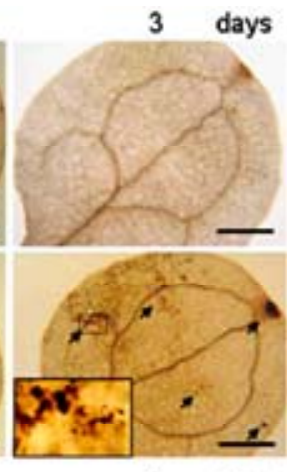

3 days

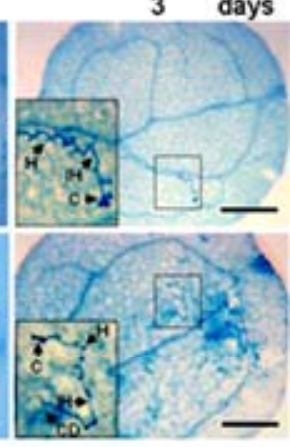

Fig. 8. Enhanced resistance of Capsicum annuum calmodulin 1 overexpression (CaCaM1-OX) transgenic Arabidopsis plants to Hyaloperonospora parasitica isolate Noco2 infection. A, Disease symptoms on wild-type and transgenic plants 7 days after spray inoculation with $\mathrm{H}$. parasitica Noco2 $\left(5 \times 10^{4}\right.$ spores $\mathrm{ml}^{-1}$ ). B, Number of sporangiophores per cotyledon of wild-type and transgenic plants 7 days after inoculation. Cotyledons were classified as follows: no sporulation ( 0 sporangiophore/cotyledon), light sporulation (approximately 1 to 10 sporangiophores/cotyledon), medium sporulation (approximately 11 to 20 sporangiophores/cotyledon), or heavy sporulation (>20 sporangiophores/cotyledon). Sporangiophores were counted on more than 50 cotyledons per genotype. Average numbers of sporangiophores produced on the cotyledons of wild-type and transgenic lines are shown below each of the lines tested. Statistically significant differences between means were determined by employing the least significant difference method $(P=0.05)$. All tests were performed three times with similar results. C, 3,3'-Diaminobenzidine (DAB) staining of $H$. parasitica-infected cotyledons of wild-type and transgenic plants 1 and 3 days after inoculation. The reddish-brown coloration of the DAB polymer is indicated by arrows. DAB-stained cells are shown at higher magnification in the insets. D, Trypan blue staining of downy mildew-infected cotyledons of wild-type and transgenic plants 1 and 3 days after inoculation. Trypan blue-stained fungal structures and dead cells are shown at higher magnification in the insets. Bars $=250 \mu \mathrm{m}$. C: Conidiospores, IH: infection hyphae, $\mathrm{H}$ : haustorium, and CD: cell death. 
patterns of CaCaMl induced by wounding and MeJA treatments were similar to those induced by mock and virulent $X$. campestris pv. vesicatoria infiltration. These results suggest that the expression of CaCaMl can be triggered by MeJA pathway-related wounding stress. However, strengthened and prolonged expression of $\mathrm{CaCaM1}$ during resistance response may require increased endogenous levels of SA.

The CaCaM1 transcript gradually increased up to $25 \mathrm{~h}$ following treatment with ABA. However, drought stress only induced $C a C a M 1$ within $1 \mathrm{~h}$ after treatment and the expression level rapidly decreased thereafter. This suggests that the expression of $\mathrm{CaCaM1}$ could be induced and maintained by ABA treatment but suppressed under drought stress conditions. Early expression of $\mathrm{CaCaM1}$ in pepper plants subjected to drought stresses could be due to wounding stress caused by washing away soil particles attached to the roots. Interestingly, the gradually increasing expression patterns of $\mathrm{CaCaMI}$ caused by ABA were similar to those caused by $\mathrm{H}_{2} \mathrm{O}_{2}$ treatment. Increasing evidence indicates that $\mathrm{ABA}$ also mediates plant responses to pathogen invasions by regulating the accumulation of ROS such as $\mathrm{O}_{2}^{-}$and $\mathrm{H}_{2} \mathrm{O}_{2}$ (Pei et al. 2000; Laloi et al. 2004; Hu et al. 2005, 2007; Sang et al. 2008). However, the role of $\mathrm{ABA}$ in disease resistance remains largely unknown (Hwang et al. 2008). Therefore, further studies are required to gain insights into role of ABA- or $\mathrm{H}_{2} \mathrm{O}_{2}$-induced $\mathrm{CaCaMI}$ expression in the defense responses of pepper plants.

To examine the effect of a loss-of-function of $\mathrm{CaCaMI}$ in defense responses, we performed the Tobacco rattle virusbased VIGS technique in pepper plants (Choi et al. 2007, 2008; Lee et al. 2008). Unfortunately, we could not generate CaCaM1-silenced pepper plants. Pepper plants failed to develop true leaves and died following cotyledon infiltration of Agrobacterium strains carrying $\mathrm{CaCaM1-silencing} \mathrm{constructs}$ but not empty vector control constructs. This suggests that $\mathrm{CaCaM1}$ also plays an important role in normal organ development. Therefore, we used an Agrobacterium-mediated transient assay to examine the role of $\mathrm{CaCaM1}$ in pepper plants. Interestingly, the transient expression of CaCaM1 induced enhanced ROS and NO accumulation, local cell death, and $P R$ gene induction. However, overexpression of $\mathrm{CaCaMl}$ in transgenic Arabidopsis induced neither ROS and NO accumulation nor local cell death on healthy leaves. This suggests that CaCaM1 may require other host factors to activate ROS and
NO generation for cell death in plants. CaCaMl-OX-transgenic Arabidopsis also exhibited strong ROS and NO accumulation and a cell death phenotype upon infection with microbial pathogens. Our pharmacological studies using the calciumchannel blocker $\mathrm{LaCl}_{3}$ also revealed a requirement for calcium channel activation for $\mathrm{CaCaMl}$ function in the generation of ROS and NO, which are responsible for cellular defense responses, including cell death regulation and $P R$ gene expression in plants (Grant et al. 2000; Garcia-Brugger et al. 2006; Asai et al. 2008). In addition, treatment with W7, which inhibits the formation of $\mathrm{Ca}^{2+}$-bound $\mathrm{CaM}$ by selectively binding to CaM protein (Ma et al. 2008), significantly blocked NO generation and symptom development in CaCaM1-OX leaves infected with virulent $P$. syringae pv. tomato DC3000. This suggests that the increase in $\left[\mathrm{Ca}^{2+}\right]_{\text {cyt }}$ elicited by pathogen infection may lead to the production of $\mathrm{Ca}^{2+}$-bound forms of $\mathrm{CaCaM} 1$ which, in turn, activate defense-related host proteins to promote ROS and NO generation for cell death in plants. In contrast, exogenous application of W7 failed to block the $\mathrm{CaCaMl-induced} \mathrm{NO}$ generation and hypersensitive cell death in pepper leaves infiltrated with Agrobacterium spp. carrying the 35S:CaCaM1 construct. This may be due to the undesired, adverse effect of W7 on Agrobacterium-mediated CaCaMI transient expression in pepper leaves. The bacterial titer of Agrobacterium spp. $\left(\mathrm{OD}_{600}>0.2\right)$ used in pepper leaves may also be too high to be compared with that of $P$. syringae pv. tomato $\mathrm{DC} 3000\left(\mathrm{OD}_{600}\right.$ of 0.02 is the equivalent of $10^{7} \mathrm{CFU}$ $\mathrm{ml}^{-1}$ ) in Arabidopsis leaves.

To examine the cellular function of $C a C a M 1$, we established transgenic Arabidopsis plants that overexpressed $\mathrm{CaCaMl}$, because of the extremely low efficiencies of transformation of pepper plants. Interestingly, ectopic overexpression of $\mathrm{CaCaMI}$ induced the constitutive expression of $P R$ genes in uninfected Arabidopsis plants. The expression levels of Arabidopsis SAresponsive $P R 1$ were stronger than the expression levels of MeJA-responsive PDF1.2 in CaCaM1-OX Arabidopsis. Consistent with these results, CaCaM1-OX transgenic lines exhibited significantly enhanced resistance to the hemibiotrophic bacterial pathogen $P$. syringae pv. tomato DC3000 and the biotrophic oomycete pathogen $H$. parasitica Noco2 infection, accompanied by enhanced ROS accumulation, HR development, and PRI induction. However, CaCaMl-OX transgenic lines exhibited enhanced susceptibility to infection with the
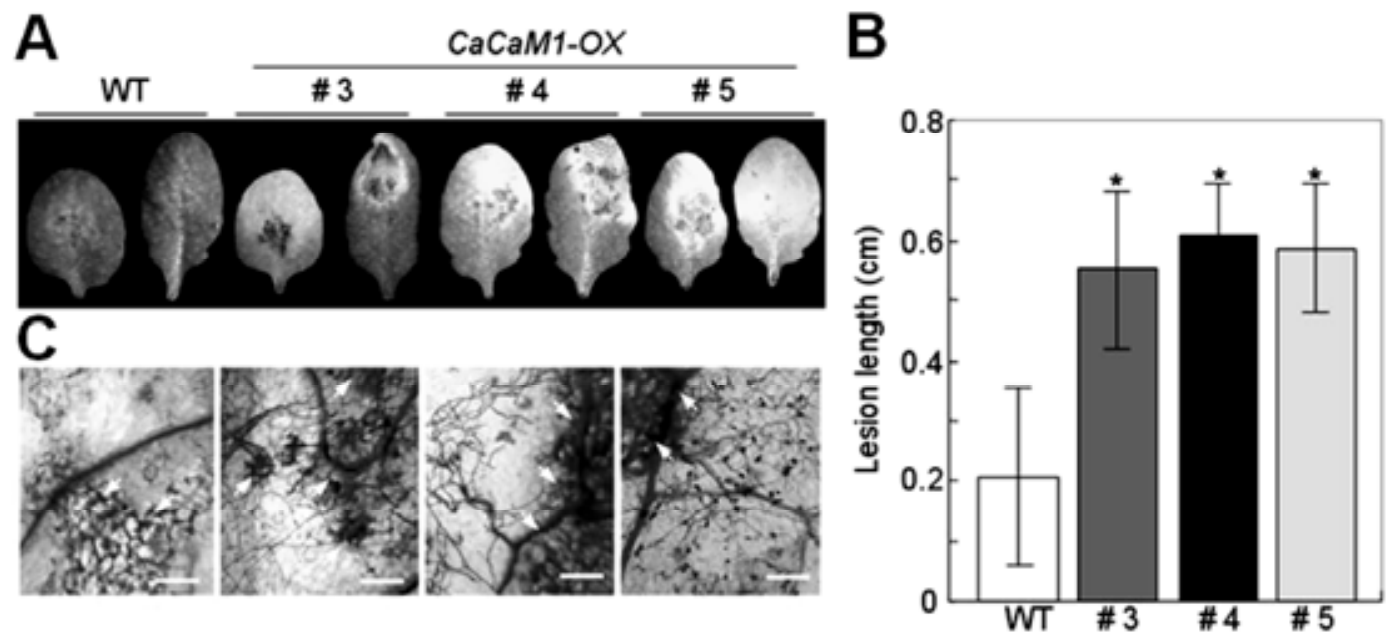

Fig. 9. Enhanced susceptibility of Capsicum annuum calmodulin 1 overexpression (CaCaM1-OX) transgenic Arabidopsis plants to Alternaria brassicicola KACC40036 infection. A, Disease symptoms on wild-type and transgenic leaves 7 days after droplet inoculation with $A$. brassicicola $\left(5 \times 10^{5}\right.$ spores $^{\mathrm{ml}^{-1}}$ ). B, Diameters of chlorotic lesions developed on the leaves of wild-type and transgenic plants 7 days after inoculation. Asterisks indicate significant differences as determined by Student's $t$ test $(P<0.05)$. C, Trypan blue staining of leaves of wild-type and transgenic plants 7 days after inoculation with $A$. brassicicola. Host cell death is indicated by arrows. Bars $=200 \mu \mathrm{m}$. 
necrotrophic fungal pathogen A. brassicicola, although MeJAresponsive PDF1.2 expression was elevated. In general, the SA-dependent plant defense pathway is known to be antagonistic to the MeJA-dependent pathway (Kunkel and Brooks 2002; Koornneef and Pieterse 2008). Thus, the enhanced susceptibility of $\mathrm{CaCaM1-OX}$ transgenic plants may be due to the possibility that $\mathrm{CaCaMI}$-induced SA-dependent pathways are sufficient to antagonize MeJA-dependent pathways during $A$. brassicicola infection in Arabidopsis. Alternatively, CaCaM1dependent susceptible cell death response may facilitate the growth of the necrotrophic fungal pathogen A. brassicicola (Lawrence et al. 2008). These findings suggest that overexpression of $C a C a M 1$ differentially confers resistance or susceptibility, depending on the pathogen lifestyle in Arabidopsis.

Taking all the available evidence together, the present study provides clues for the elucidation of the cellular functions of pepper $\mathrm{CaCaMl}$ in plant defense responses. Agrobacterium spp.-mediated transient expression of CaCaM1 induced ROS and NO, $P R$ genes, and cell death in pepper leaves, ultimately leading to an enhanced local acquired resistance (LAR). Interestingly, ectopic overexpression of $\mathrm{CaCaM1}$ also conferred significantly enhanced disease resistance of Arabidopsis to $P$. syringae pv. tomato DC3000 and H. parasitica Noco2 but not to A. brassicicola, which was accompanied by the enhanced expression of SA-responsive $P R 1$. In conclusion, we propose a working model for the CaCaM1-mediated defense signaling pathway in plants during biotrophic and hemibiotrophic pathogen infection (Fig. 10). SA-mediated defense signaling triggered by these pathogens induces strengthened and prolonged expression of $\mathrm{CaCaM1}$. Furthermore, elevation of $\left[\mathrm{Ca}^{2+}\right]_{\mathrm{cyt}} \mathrm{lev}$ els by calcium-channel activation (Grant et al. 2000) contributes to the generation of $\mathrm{Ca}^{2+}$-bound $\mathrm{CaCaM} 1$. The $\mathrm{Ca}^{2+}$ bound $\mathrm{CaCaM} 1$ requires unknown host target proteins for ROS and NO generation to trigger cell death in plants. More recently, experiments using Arabidopsis T-DNA mutants and $\mathrm{CaM}$ antagonists have revealed that $\left[\mathrm{Ca}^{2+}\right]_{\text {cyt }}$ elevation is linked to downstream NO generation and disease resistance through the action of CaM or CaM-like proteins (Ma et al. 2008). In animal cells, nitric oxide synthase is known to use $\mathrm{Ca}^{2+}$-bound $\mathrm{CaM}$ as a cofactor to catalyze NO synthesis (Nathan and Xie 1994). However, homologues in plants have not yet been identified (Guo et al. 2003; Crawford 2006). Thus, further studies of $\mathrm{CaCaM1-binding} \mathrm{proteins} \mathrm{are} \mathrm{required} \mathrm{to} \mathrm{gain} \mathrm{new} \mathrm{insights}$ into the mechanisms of CaCaM1-mediated ROS and NO generation and cell death in pepper plants. Finally, local cell death induced by $\mathrm{CaCaM1}$ expression activates SA-mediated LAR in pepper plants (Choi et al. 2007).

\section{MATERIALS AND METHODS}

Plant growth conditions.

Pepper (C. annuum L.) and Arabidopsis (Arabidopsis thaliana ecotype Columbia) plants were grown as previously described (Lee et al. 2006; Hong and Hwang 2009; Lee and Hwang 2009).

Isolation and sequence analysis of the $\mathrm{CaCaM1}$ cDNA.

To isolate pathogen-inducible cDNAs, differential hybridization screening was performed using the pepper cDNA library as previously described (Jung and Hwang 2000; Kim and Hwang 2000). Among cDNA clones exhibiting strong and differential hybridization, the CaCaMl cDNA (accession no. EU935058) was selected and sequenced

\section{Pathogen inoculation and histochemical staining.}

The virulent strain Ds1 and the avirulent strain Bv5-4a of $X$. campestris pv. vesicatoria were used to inoculate pepper plants as previously described (Lee et al. 2006; Kim et al. 2007). P. syringae pv. tomato DC3000, H. parasitica Noco2, and Alternaria brassicicola KACC40036 were also used to inoculate Arabidopsis as previously described (Choi et al. 2007, 2008; Lee et al. 2008). For NO measurements, bacterial suspensions $\left(10^{7} \mathrm{CFU} \mathrm{ml^{-1 }}\right)$ supplemented with or without 2 $\mathrm{mM} \mathrm{LaCl} 3,200 \mu \mathrm{M} \mathrm{W7}$, and $200 \mu \mathrm{M}$ W5 were infiltrated into the abaxial side of Arabidopsis leaves using a needleless syringe.

To visualize hypersensitive cell death and mycelial growth of $H$. parasitica Noco 2 and A. brassicicola, lactophenol-trypan blue staining was performed as described by Koch and Slusarenko (1990). Infected leaves were sampled at various time points after inoculation and stained with lactophenoltrypan blue solution ( $10 \mathrm{ml}$ of lactic acid, $10 \mathrm{ml}$ of glycerol, 10 $\mathrm{g}$ of phenol, and $10 \mathrm{mg}$ of trypan blue, dissolved in $10 \mathrm{ml}$ of distilled water). Whole leaves were boiled for $1 \mathrm{~min}$ in the staining solution and then decolorized in chloral hydrate solution $(2.5 \mathrm{~g}$ of chloral hydrate dissolved in $1 \mathrm{ml}$ of distilled water). They were mounted in $60 \%$ glycerol and representative phenotypes were photographed with a light microscope (Olympus BH-2, Tokyo).

\section{Abiotic elicitor and environmental stress treatment.}

SA $(5 \mathrm{mM}), \mathrm{MeJA}(100 \mu \mathrm{M}), \mathrm{ABA}(100 \mu \mathrm{M})$, and $\mathrm{H}_{2} \mathrm{O}_{2}(10$ $\mathrm{mM})$ were sprayed onto pepper plants at the six-leaf stage. MeJA-treated plantlets were incubated in a plastic bag. For ethylene treatment, whole pepper plants were removed from soil and transferred to a water-containing sealed container (4 liters), and ethylene was injected to yield a final concentration of $5 \mu$ liter $^{-1}$. For drought stress treatment, pepper plants were

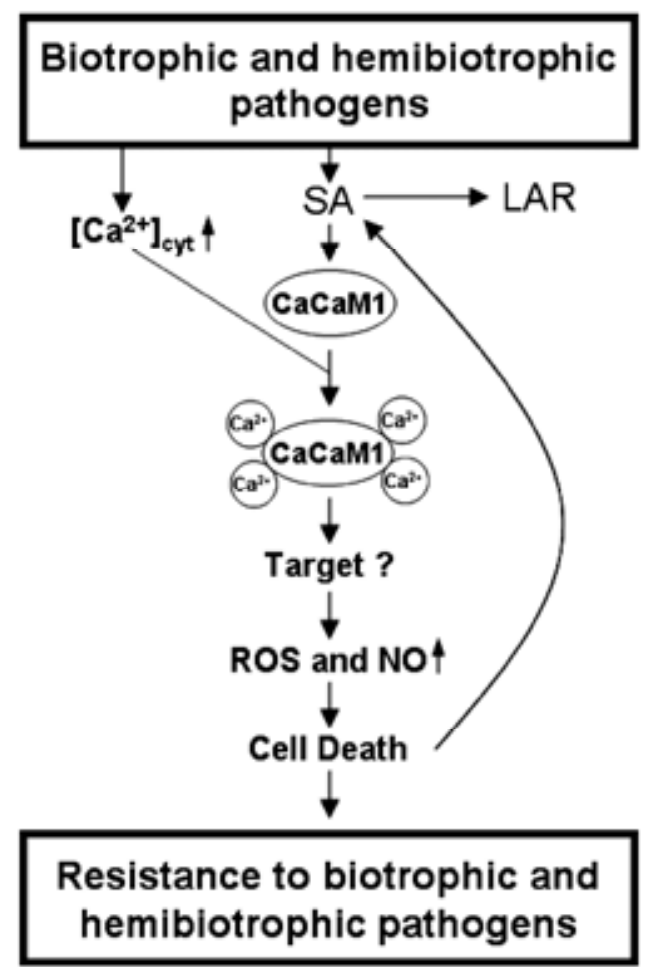

Fig. 10. Proposed model for the Capsicum annuum calmodulin 1 (CaCaM1)-mediated defense signaling pathway in plants infected with biotrophic and hemibiotrophic pathogens. Pathogen-induced CaCaMI expression and cytosolic $\mathrm{Ca}^{2+}$ elevation produces $\mathrm{Ca}^{2+}$-bound $\mathrm{CaCaM} 1$, which thus activates reactive oxygen species (ROS) and nitric oxide (NO) generation through unknown host target proteins. CaCaM1 induces ROSand NO-triggered cell death in pepper plants, ultimately leading to enhanced local acquired resistance (LAR). 
removed from soil and their roots were washed with tap water to remove residual soil particles. The treated pepper plants were incubated in a growth room at $27 \pm 1^{\circ} \mathrm{C}$ with photons at approximately $80 \mu \mathrm{mol} \mathrm{m} \mathrm{m}^{-2} \mathrm{~s}^{-1}$. Wounding stress was performed by injuring leaves with needles. For cold stress, pepper plants were transferred to a $4^{\circ} \mathrm{C}$ incubator. Leaves treated with various elicitors and subjected to stresses were cut from the plants at various time points, frozen in liquid nitrogen, and stored at $-70^{\circ} \mathrm{C}$ until used for RNA isolation.

\section{RNA gel blot and RT-PCR analyses.}

Total RNA was extracted from various organs of pepper plants as described by Hong and associates (2007). Total RNA was also extracted from the aerial portion of Arabidopsis plants using the TRIzol Reagent (Invitrogen, Carlsbad, CA, U.S.A.) according to the manufacturer's instructions. After electrophoresis on $1.2 \%$ (wt/vol) formaldehyde agarose gels, RNA was transferred onto Hybond $\mathrm{N}+$ membranes (Amersham, Little Chalfont, U.K.) and hybridized overnight with ${ }^{32} \mathrm{P}$-labeled $\mathrm{CaCaM1}$ cDNA in hybridization solution $(1 \mathrm{mM}$ EDTA, 7\% sodium dodecyl sulfate, $250 \mathrm{mM} \mathrm{Na} \mathrm{HPO}_{4}$, and $5 \%$ dextran sulfate at $65^{\circ} \mathrm{C}$ ). To generate a gene-specific probe, the coding region of the $\mathrm{CaCaMl}$ was amplified using the primers 5'-ATGGCAGATCAGTTGACTGATG-3' (forward) and 5'-CTTGGCCATCATGACCTTAAC-3' (reverse). RNA gel blot analyses were performed three times with similar results.

Pepper and Arabidopsis cDNA was synthesized from total RNA $(2 \mu \mathrm{g})$ using AMV reverse transcriptase (Roche, Mannheim, Germany) with oligo $\mathrm{p}(\mathrm{dT})_{15}$ as a primer (Roche), according to the manufacturer's instruction. RT-PCR was performed by using ExTaq polymerase (Takara Biomedicals, Otsu, Japan). The reaction mixture contained aliquots of $1 \mu \mathrm{l}$ of RT-reaction product, $0.5 \mu \mathrm{M}$ each of forward and reverse primers, 1× ExTaq buffer, $250 \mathrm{nM}$ dNTPs, and 0.5 units of ExTaq polymerase in a $50-\mu$ solution. RT-PCR conditions were $95^{\circ} \mathrm{C}$ for $10 \mathrm{~min}$ and 30 cycles of $95^{\circ} \mathrm{C}$ for $30 \mathrm{~s}, 52^{\circ} \mathrm{C}$ for $30 \mathrm{~s}$, and $72^{\circ} \mathrm{C}$ for $30 \mathrm{~s}$. Single bands of PCR products were confirmed on an agarose gel. The following gene-specific primers were used for RT-PCR analyses: 5'-ATGGCAGATCA GTTGACTGATG-3' (forward) and 5'-CTTGGCCATCATGA CCTTAAC-3' (reverse) for CaCaM1 (accession no. EU935058); 5'-CAGGATGCAACACTCTGGTGG-3' (forward) and 5'-AT CAAAGGCCGGTTGGTC-3' (reverse) for CaBPRl (accession no. AF053343); 5'-TGTCGAAGGTGGTCCAATAAA-3' (forward) and 5'-TAGACAGAAGGATTGGCGAGG-3' (reverse) for CaPR10 (accession no. AF244121); 5'-ATCTGTAC CAGCTTGCACGTGT-3' (forward) and 5'-CCCTCACTGTG GCCTTGG-3' (reverse) for CaPOAl (accession no. AF442387); 5'-ATGAATTTTACTGGCTTCTCG-3' (forward) and 5'-TTA GTATGGCTTCTCGTTCACAT-3' (reverse) for AtPRl (accession no. At2G14610); 5'-ATGGCTAAGTTTGCTTCCATC-3' (forward) and 5'-TTAACATGGGACGTAAGTAA-3' (reverse) for AtPDF1.2 (accession no. At5G44420); 5'-GGTAGTGAAT CAGGAGCTGAGC-3' (forward) and 5'-TCCACCTCCGGAG ATAGGTA-3' (reverse) for AtRD29A (accession no. D13044); and 5'-CAAGACAGGAGAAATATGTCTCG-3' (forward) and 5'-ATCCTTTCTTAGGCATAGCG-3' (reverse) for AtUBQ (accession no. At3g62250).

\section{Plant transformation.}

To generate transgenic Arabidopsis plants expressing the CaCaMl gene, the full-length CaCaMl cDNA was inserted into the vector pBIN35S behind the CaMV35S ribosomal RNA promoter. The construct was transferred to Agrobacterium tumefaciens GV3101 by electroporation. Transgenic Arabidopsis plants were created following the floral dipping method (Clough and Bent 1998). Transgenic Arabidopsis plants harboring 35S:CaCaM1 were selected by planting seed on an MS plate (Duchefa, Haarlem, The Netherlands) containing kanamycin at $50 \mu \mathrm{g} \mathrm{ml}^{-1}$. Expression of $\mathrm{CaCaMl}$ in transgenic Arabidopsis plants was confirmed by PCR amplification of the transgene.

\section{Agrobacterium spp.-mediated transient assays.}

A. tumefaciens GV3101 containing empty vector (pBIN:00) or the pBIN35S:CaCaM1 construct was grown overnight at $28^{\circ} \mathrm{C}$ in YEP media (10 $\mathrm{g}$ of yeast extract, $10 \mathrm{~g}$ of peptone, and $5 \mathrm{~g}$ of $\mathrm{NaCl}$ [Difco, Detroit] per liter; $\mathrm{pH} 7.5$ adjusted with $\mathrm{NaOH})$ containing kanamycin at $50 \mu \mathrm{g} \mathrm{ml}^{-1}$ and rifampicin at $100 \mu \mathrm{g} \mathrm{ml}^{-1}$. The bacterial cells collected by centrifugation were suspended in infiltration buffer $\left(10 \mathrm{mM} \mathrm{MgCl}_{2} ; 10 \mathrm{mM}\right.$ 2-[N-morpholino] ethane sulfonic acid, pH 5.7; and $200 \mu \mathrm{M}$ acetosyringone) to a final $\mathrm{OD}_{600}$ of 1.0 , followed by serial dilutions. Bacterial suspensions supplemented with or without 2 $\mathrm{mM} \mathrm{LaCl}{ }_{3}$ were infiltrated into the abaxial side of pepper leaves with a needleless syringe.

\section{NO measurements.}

In planta NO accumulation was monitored using the NOsensitive dye DAF-2DA (Sigma-Aldrich, St. Louis), as described by Asai and associates (2008). Pepper and Arabidopsis leaves were infiltrated with $200 \mathrm{mM}$ sodium phosphate buffer at $\mathrm{pH}$ 7.4, including $12.5 \mu \mathrm{M}$ DAF-2DA, using a needleless syringe. Plants were incubated for $1 \mathrm{~h}$ in the dark at room temperature. Fluorescence from diaminotriazolofluorescein, the reaction product of DAF-2DA with NO, was observed using a MRC-1024 confocal laser-scanning microscope (Bio-Rad, Hercules, CA, U.S.A.). The excitation was at $470 \mathrm{~nm}$ and the emission images at $525 \mathrm{~nm}$ were obtained at constant acquisition time. The fluorescence intensity of the digital image was determined by color histogram analysis of Photoshop CS3 (Adobe, Seattle).

\section{ACKNOWLEDGMENTS}

This work was supported by a grant (CG1133) from the Crop Functional Genomics Center of the 21st Century, Frontier Research Program funded by the Ministry of Science and Technology, Korea. We thank S. P. Dinesh-Kumar (Yale University) for the pTRV1 and pTRV2 vectors and U. Bonas (Martin-Luther-Universität) for Agrobacterium tumefaciens GV3101.

\section{LITERATURE CITED}

Ali, R., Ma, W., Lemtiri-Chlieh, F., Tsaltas, D., Leng, Q., von Bodman, S., and Berkowitz, G. A. 2007. Death don't have no mercy and neither does calcium: Arabidopsis CYCLIC NUCLEOTIDE GATED CHANNEL2 and innate immunity. Plant Cell 19:1081-1095.

Asai, S., Ohta, K., and Yoshioka, H. 2008. MAPK signaling regulates nitric oxide and NADPH oxidase-dependent oxidative burst in Nicotiana benthamiana. Plant Cell 20:1390-1406.

Bergey, D. R., and Ryan, C. A. 1999. Wound- and systemin-inducible calmodulin gene expression in tomato leaves. Plant Mol. Biol. 40:815823.

Blume, B., Nürnberger, T., Nass, N., and Scheel, D. 2000. Receptor-mediated increase in cytoplasmic free calcium required for activation of pathogen defense in parsley. Plant Cell 12:1425-1440.

Boonburapong, B., and Buaboocha, T. 2007. Genome-wide identification and analyses of the rice calmodulin and related potential calcium sensor proteins. BMC Plant Biol. 7:4.

Bouché, N., Yellin, A., Snedden, W. A., and Fromm, H. 2005. Plant-specific calmodulin-binding proteins. Annu. Rev. Plant Biol. 56:435-466.

Cheng, S. H., Willmann, M. R., Chen, H. C., and Sheen J. 2002. Calcium signaling through protein kinases. The Arabidopsis calcium-dependent protein kinase gene family. Plant Physiol. 129:469-485.

Choi, H. W., Kim, Y. J., Lee, S. C., Hong, J. K., and Hwang, B. K. 2007. Hydrogen peroxide generation by the pepper extracellular peroxidase 
$\mathrm{CaPO} 2$ activates local and systemic cell death and defense response to bacterial pathogens. Plant Physiol. 145:890-904.

Choi, H. W., Lee, B. G., Kim, N. H., Park, Y., Lim, C. W., Song, H. K., and Hwang, B. K. 2008. A role for a menthone reductase in resistance against microbial pathogens in plants. Plant Physiol. 148:383-401.

Clough, S. H., and Bent, A. F. 1998. Floral dip: A simplified method for Agrobacterium-mediated transformation of Arabidopsis thaliana. Plant J. 16:735-743.

Crawford, N. M. 2006. Mechanisms for nitric oxide synthesis in plants. J. Exp. Bot. 57:471-478.

Day, I. S., Reddy, V. S., Shad Ali, G., and Reddy, A. S. 2002. Analysis of EF-hand-containing proteins in Arabidopsis. Genome Biol. 3:RESEARCH0056.

Durner, J., Wendehenne, D., and Klessig, D. F. 1998. Defense gene induction in tobacco by nitric oxide, cyclic GMP, and cyclic ADP-ribose. Proc. Natl. Acad. Sci. U.S.A. 95:10328-10333.

Fujita, M., Fujita, Y., Noutoshi, Y., Takahashi, F., Narusaka, Y., YamaguchiShinozaki, K., and Shinozaki, K. 2006. Crosstalk between abiotic and biotic stress responses: A current view from the points of convergence in the stress signaling networks. Curr. Opin. Plant Biol. 9:436-442.

Gao, D., Knight, M. R., Trewavas, A. J., Sattelmacher, B., and Plieth, C. 2004. Self-reporting Arabidopsis expressing $\mathrm{pH}$ and $\left[\mathrm{Ca}^{2+}\right]$ indicators unveil ion dynamics in the cytoplasm and in the apoplast under abiotic stress. Plant Physiol. 134:898-908.

Garcia-Brugger, A., Lamotte, O., Vandelle, E., Bourque, S., Lecourieux, D., Poinssot, B., Wendehenne, D., and Pugin, A. 2006. Early signaling events induced by elicitors of plant defenses. Mol. Plant-Microbe Interact. 19:711-724.

Glazebrook, J. 2001. Genes controlling expression of defense responses in Arabidopsis-2001 status. Curr. Opin. Plant Biol. 4:301-308.

Grant, M., Brown, I., Adams, S., Knight, M., Ainslie, A., and Mansfield, J. 2000. The RPM1 plant disease resistance gene facilitates a rapid and sustained increase in cytosolic calcium that is necessary for the oxidative burst and hypersensitive cell death. Plant J. 23:441-450.

Guo, F. Q., Okamoto, M., and Crawford, N. M. 2003. Identification of a plant NO synthase gene involved in hormonal signaling. Science 302:100-103.

Harding, S. A., Oh, S. H., and Roberts, D. M. 1997. Transgenic tobacco expressing a foreign calmodulin gene shows an enhanced production of active oxygen species. EMBO (Eur. Mol. Biol. Organ.) J. 16:11371144.

Heo, W. D., Lee, S. H., Kim, M. C., Kim, J. C., Chung, W. S., Chun, H. J., Lee, K. J., Park, C. Y., Park, H. C., Choi, J. Y., and Cho, M. J. 1999. Involvement of specific calmodulin isoforms in salicylic acid-independent activation of plant disease resistance responses. Proc. Natl. Acad. Sci. U.S.A. 96:766-771.

Hong, J. K., and Hwang, B. K. 2009. The promoter of the pepper pathogen-induced membrane protein gene CaPIMP1 mediates environmental stress responses in plants. Planta 229:249-259.

Hong, J. K., Choi, H. W., Hwang, I. S., and Hwang, B. K. 2007. Role of a novel pathogen-induced pepper $\mathrm{C} 3-\mathrm{H}-\mathrm{C} 4$ type RING-finger protein gene, CaRFPl, in disease susceptibility and osmotic stress tolerance. Plant Mol. Biol. 63:571-588.

Hu, X., Jiang, M., Zhang, A., and Lu, J. 2005. Abscisic acid-induced apoplastic $\mathrm{H}_{2} \mathrm{O}_{2}$ accumulation up-regulates the activities of chloroplastic and cytosolic antioxidant enzymes in maize leaves. Planta 223:57-68.

Hu, X., Jiang, M., Zhang, J., Zhang, A., Lin, F., and Tan, M. 2007. Calcium-calmodulin is required for abscisic acid-induced antioxidant defense and functions both upstream and downstream of $\mathrm{H}_{2} \mathrm{O}_{2}$ production in leaves of maize (Zea mays) plants. New Phytol. 173:27-38.

Hwang, S., Kim, J., Kim, Y. H., and Kim, H. T. 2008. ABA increases susceptibility of pepper fruits to infection of anthracnose by Colletotrichum acutatum. Plant Pathol. J. 24:400-406.

Jones, J. D., and Dangl, J. L. 2006. The plant immune system. Nature 444:323-329.

Jung, H. W., and Hwang, B. K. 2000. Isolation, partial sequencing, and expression of pathogenesis-related cDNA genes from pepper leaves infected by Xanthomonas campestris pv. vesicatoria. Mol. Plant-Microbe Interact. 13:136-142.

Kim, B. S., Kim, Y. C., Shin, K. S., and Kim, J. H. 2007. Near-isogenic lines for genes conferring hypersensitive resistance to bacterial spot in chili pepper. Plant Pathol. J. 23:155-160.

Kim, M. C., Lee, S. H., Kim, J. K., Chun, H. J., Choi, M. S., Chung, W. S., Moon, B. C., Kang, C. H., Park, C. Y., Yoo, J. H., Kang, Y. H., Koo, S. C., Koo, Y. D., Jung, J. C., Kim, S. T., Schulze-Lefert, P., Lee, S. Y., and Cho, M. J. 2002. Mlo, a modulator of plant defense and cell death, is a novel calmodulin-binding protein. J. Biol. Chem. 277:19304-19314.

Kim, Y. J., and Hwang, B. K. 2000. Pepper gene encoding a basic pathogenesis related 1 protein is pathogen and ethylene inducible. Physiol. Plant. 108:51-60.
Knight, H., and Knight, M. R. 2001. Abiotic stress signalling pathways: Specificity and cross-talk. Trends Plant Sci. 6:262-267.

Koch, E., and Slusarenko, A. 1990. Arabidopsis is susceptible to infection by a downy mildew fungus. Plant Cell 2:437-445.

Koornneef, A., and Pieterse, C. M. J. 2008. Cross talk in defense signaling. Plant Physiol. 146:839-844.

Kunkel, B. N., and Brooks, D. M. 2002. Cross talk between signaling pathways in pathogen defense. Curr. Opin. Plant Biol. 5:325-331.

Laloi, C., Mestres-Ortega, D., Marco, Y., Meyer, Y., and Reichheld, J. P. 2004. The Arabidopsis cytosolic thioredoxin $h 5$ gene induction by oxidative stress and its w-box-mediated response to pathogen elicitor. Plant Physiol. 134:1006-1016.

Lawrence, C. B., Mitchell T. K., Craven, K. D., Cho, Y., Cramer, R. A., Jr., and Kim, K.-H. 2008. At death's door: Alternaria pathogenicity mechanisms. Plant Pathol. J. 24:101-111.

Lecourieux, D., Ranjeva, R., and Pugin, A. 2006. Calcium in plant defence-signaling pathways. New Phytol. 171:249-269.

Lee, S. C., and Hwang, B. K. 2005. Induction of some defense-related genes and oxidative burst is required for the establishment of systemic acquired resistance in Capsicum апnиит. Planta 221:790-800.

Lee, S. C., and Hwang, B. K. 2009. Functional roles of the pepper antimicrobial protein gene, $C a A M P 1$, in abscisic acid signaling, and salt and drought tolerance in Arabidopsis. Planta 229:383-391.

Lee, S. C., Choi, H. W., Hwang, I. S., Choi, D. S., and Hwang, B. K. 2006 Functional roles of the pepper pathogen-induced bZIP transcription factor, CAbZIP1, in enhanced resistance to pathogen infection and environmental stresses. Planta 224:1209-1225.

Lee, S. C., Hwang, I. S., Choi, H. W., and Hwang, B. K. 2008. Involvement of the pepper antimicrobial protein CaAMP1 gene in broad spectrum disease resistance. Plant Physiol. 148:1004-1020.

Lee, S. H., Kim, J. C., Lee, M. S., Heo, W. D., Seo, H. Y., Yoon, H. W., Hong, J. C., Lee, S. Y., Bahk, J. D., Hwang, I., and Cho, M. J. 1995. Identification of a novel divergent calmodulin isoform from soybean which has differential ability to activate calmodulin-dependent enzymes. J. Biol. Chem. 270:21806-21812.

Luan, S., Kudla, J., Rodriguez-Concepcion, M., Yalovsky, S., and Gruissem, W. 2002. Calmodulins and calcineurin B-like proteins: Calcium sensors for specific signal response coupling in plants. Plant Cell 14:S389-400.

Ludwig, A. A., Romeis, T., and Jones, J. D. 2004. CDPK-mediated signalling pathways: Specificity and cross-talk. J. Exp. Bot. 55:181-188.

Ma, W., and Berkowitz, G. A. 2007. The grateful dead: Calcium and cell death in plant innate immunity. Cell. Microbiol. 9:2571-2585.

Ma, W., Smigel, A., Tsai, Y. C., Braam, J., and Berkowitz, G. A. 2008. Innate immunity signaling: Cytosolic $\mathrm{Ca}^{2+}$ elevation is linked to downstream nitric oxide generation through the activation of calmodulin or a calmodulin-like protein. Plant Physiol. 148:818-828.

Nathan, C., and Xie, Q. W. 1994. Nitric oxide synthases: Roles, tolls, and controls. Cell 78:915-918.

Pei, Z. M., Murata, Y., Benning, G., Thomine, S., Klüsener, B., Allen, G. J., Grill, E., and Schroeder, J. I. 2000. Calcium channels activated by hydrogen peroxide mediate abscisic acid signaling in guard cells. Nature 406:731-734.

Pike, S. M., Zhang, X., and Gassmann, W. 2005. Electrophysiological characterization of the Arabidopsis avrRpt2-specific hypersensitive response in the absence of other bacterial signals. Plant Physiol 138:1009-1017.

Popescu, S. C., Popescu, G. V., Bachan, S., Zhang, Z., Seay, M., Gerstein, M., Snyder, M., and Dinesh-Kumar, S. P. 2007. Differential binding of calmodulin-related proteins to their targets revealed through high-density Arabidopsis protein microarrays. Proc. Natl. Acad. Sci. U.S.A. 104:4730-4735

Price, A. H., Taylor, A., Ripley, S. J., Griffiths, A., Trewavas, A. J., and Knight, M. R. 1994. Oxidative signals in tobacco increase cytosolic calcium. Plant Cell 6:1301-1310.

Rainaldi, M., Yamniuk, A. P., Murase, T., and Vogel, H. J. 2007. Calciumdependent and -independent binding of soybean calmodulin isoforms to the calmodulin binding domain of tobacco MAPK phosphatase-1. J. Biol. Chem. 282:6031-6042.

Reddy, A. S., Day, I. S., Narasimhulu, S. B., Safadi, F., Reddy, V. S., Golovkin, M., and Harnly, M. J. 2002. Isolation and characterization of a novel calmodulin-binding protein from potato. J. Biol. Chem. 277:4206-4214.

Roberts, D. M. 1993. Protein kinases with calmodulin-like domains: Novel targets of calcium signals in plants. Curr. Opin. Cell Biol. 5:242-246.

Romeis, T., Ludwig, A. A., Martin, R., and Jones, J. D. 2001. Calcium-dependent protein kinases play an essential role in a plant defence response. EMBO (Eur. Mol. Biol. Organ.) J. 20:5556-5567.

Sanders, D., Pelloux, J., Brownlee, C., and Harper, J. F. 1999. Communicating with calcium. Plant Cell 11:691-706.

Sanders, D., Pelloux, J., Brownlee, C., and Harper, J. F. 2002. Calcium at 
the crossroads of signaling. Plant Cell 14:S401-417.

Sang, J., Zhang, A., Lin, F., Tan, M., and Jiang, M. 2008. Cross-talk between calcium-calmodulin and nitric oxide in abscisic acid signaling in leaves of maize plants. Cell Res. 18:577-588.

Takabatake, R., Karita, E., Seo, S., Mitsuhara, I., Kuchitsu, K., and Ohashi, Y. 2007. Pathogen-induced calmodulin isoforms in basal resistance against bacterial and fungal pathogens in tobacco. Plant Cell Physiol. 48:414-423.

Takezawa, D., Liu, Z. H., An, G., and Poovaiah, B. W. 1995. Calmodulin gene family in potato: Developmental and touch-induced expression of the mRNA encoding a novel isoform. Plant Mol. Biol. 27:693-703.

Thomma, B. P., Eggermont, K., Penninckx, I. A., Mauch-Mani, B., Vogelsang, R., Cammue, B. P., and Broekaert, W. F. 1998. Separate jasmonate-dependent and salicylate-dependent defense-response pathways in Arabidopsis are essential for resistance to distinct microbial patho- gens. Proc. Natl. Acad. Sci. U.S.A. 95:15107-15111.

Torres, M. A., Jones, J. D., and Dangl, J. L. 2005. Pathogen-induced, NADPH oxidase-derived reactive oxygen intermediates suppress spread of cell death in Arabidopsis thaliana. Nat. Genet. 37:1130-1134.

White, P. J., and Broadley, M. R. 2003. Calcium in plants. Ann. Bot. 92:487-511.

Xu, H., and Heath, M. C. 1998. Role of calcium in signal transduction during the hypersensitive response caused by basidiospore-derived infection of the cowpea rust fungus. Plant Cell 10:585-598.

Yamakawa, H., Mitsuhara, I., Ito, N., Seo, S., Kamada, H., and Ohashi, Y. 2001. Transcriptionally and post-transcriptionally regulated response of 13 calmodulin genes to Tobacco mosaic virus-induced cell death and wounding in tobacco plant. Eur. J. Biochem. 268:3916-3929.

Zeevaart, J. A. D., and Creelman, R. A. 1998. Metabolism and physiology of abscisic acid. Annu. Rev. Plant Physiol. Plant Mol. Biol. 39:439-473. 